\title{
Simple Retrofit High-Efficiency Natural Gas Water Heater Field Test
}

Ben Schoenbauer NorthernSTAR 


\section{NOTICE}

This report was prepared as an account of work sponsored by an agency of the United States government. Neither the United States government nor any agency thereof, nor any of their employees, subcontractors, or affiliated partners makes any warranty, express or implied, or assumes any legal liability or responsibility for the accuracy, completeness, or usefulness of any information, apparatus, product, or process disclosed, or represents that its use would not infringe privately owned rights. Reference herein to any specific commercial product, process, or service by trade name, trademark, manufacturer, or otherwise does not necessarily constitute or imply its endorsement, recommendation, or favoring by the United States government or any agency thereof. The views and opinions of authors expressed herein do not necessarily state or reflect those of the United States government or any agency thereof.

This report is available at no cost from the National Renewable Energy Laboratory (NREL) at www.nrel.gov/publications.

Available electronically at SciTech Connect http:/www.osti.gov/scitech

Available for a processing fee to U.S. Department of Energy and its contractors, in paper, from:

U.S. Department of Energy

Office of Scientific and Technical Information

P.O. Box 62

Oak Ridge, TN 37831-0062

OSTI http://www.osti.gov

Phone: 865.576.8401

Fax: 865.576.5728

Email: reports@osti.gov

Available for sale to the public, in paper, from:

U.S. Department of Commerce

National Technical Information Service

5301 Shawnee Road

Alexandria, VA 22312

NTIS http://www.ntis.gov

Phone: 800.553 .6847 or 703.605 .6000

Fax: 703.605.6900

Email: orders@ntis.gov 


\title{
Simple Retrofit High-Efficiency Natural Gas Water Heater Field Test
}

\author{
Prepared for: \\ The National Renewable Energy Laboratory \\ On behalf of the U.S. Department of Energy’s Building America Program \\ Office of Energy Efficiency and Renewable Energy \\ 15013 Denver West Parkway \\ Golden, CO 80401 \\ NREL Contract No. DE-AC36-08GO28308
}

Prepared by:

Ben Schoenbauer

NorthernSTAR

2004 Folwell Ave.

St. Paul, MN 55108

NREL Technical Monitor: Stacey Rothgeb

Prepared under Subcontract No. KNDJ-0-40338-05

March 2017 
The work presented in this report does not represent performance of any product relative to regulated minimum efficiency requirements.

The laboratory and/or field sites used for this work are not certified rating test facilities. The conditions and methods under which products were characterized for this work differ from standard rating conditions, as described.

Because the methods and conditions differ, the reported results are not comparable to rated product performance and should only be used to estimate performance under the measured conditions. 


\section{Contents}

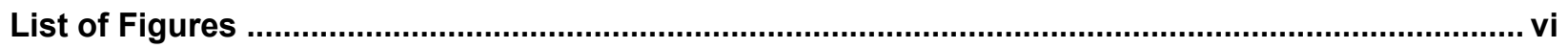

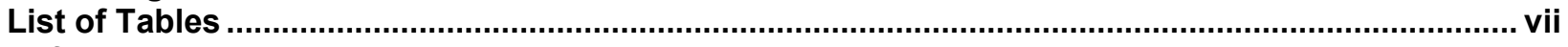

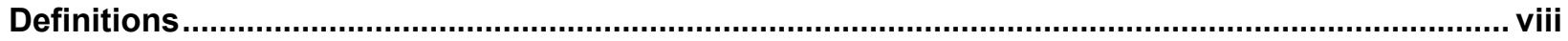

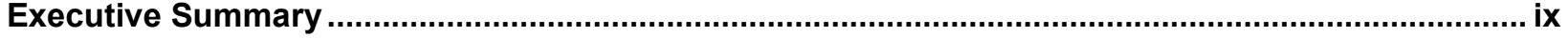

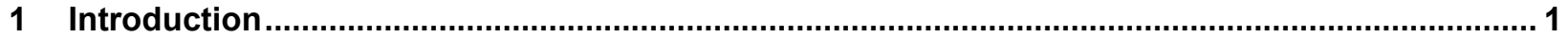

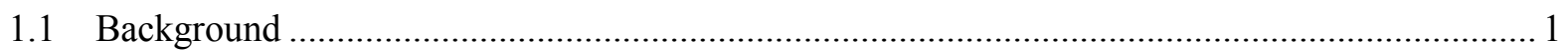

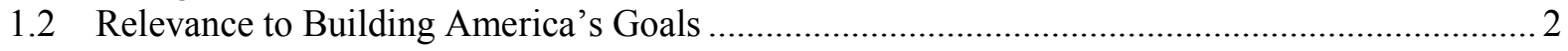

2 Experiment

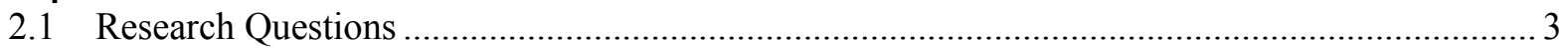

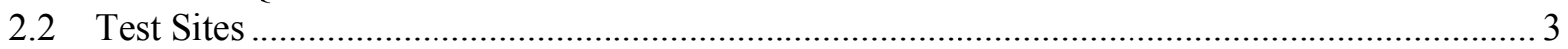

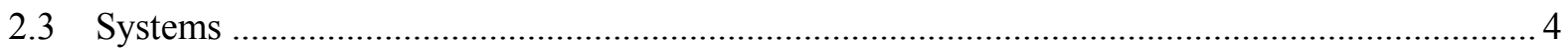

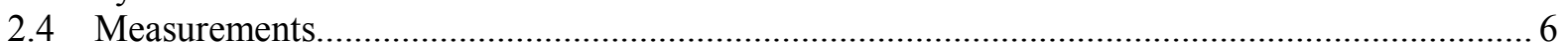

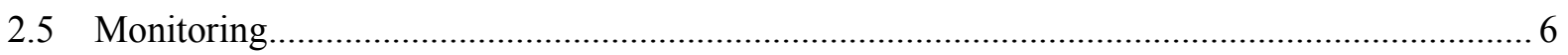

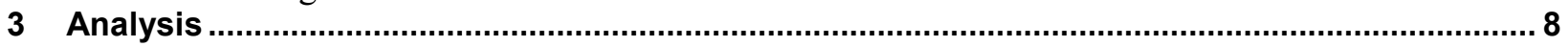

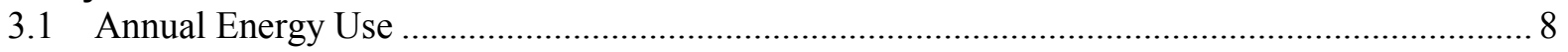

3.1.1 Seasonal Variation and Annual Average Inlet Water Temperature .............................. 8

3.1.2 Inlet Water Temperature and Domestic Hot Water Demand ..................................... 9

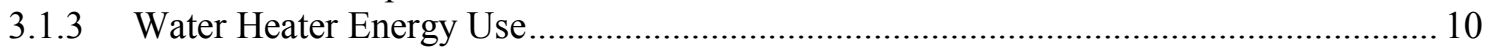

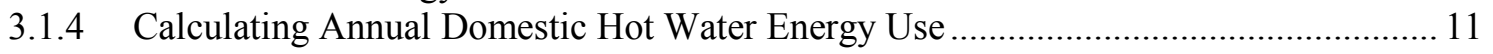

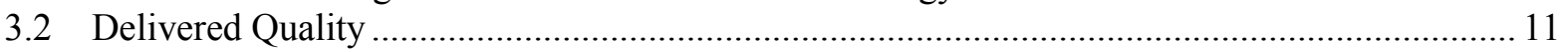

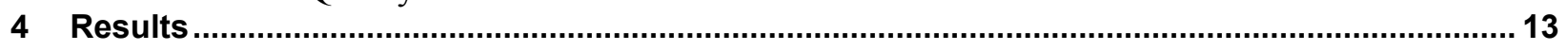

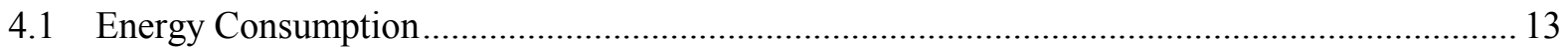

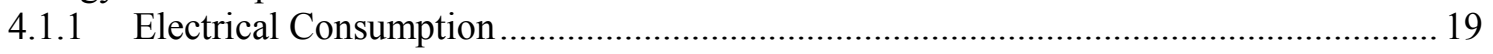

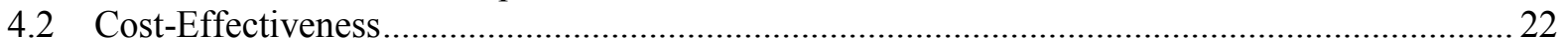

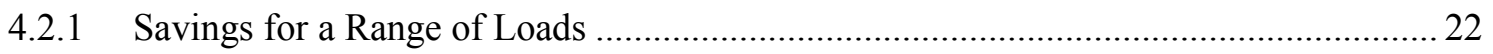

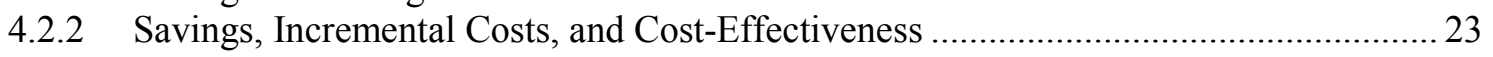

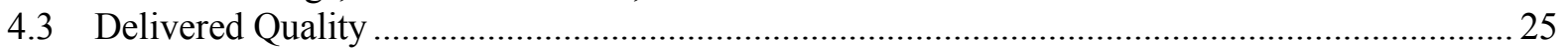

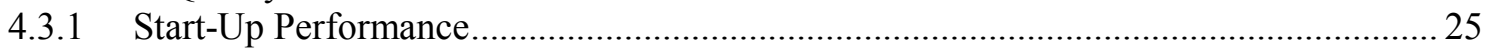

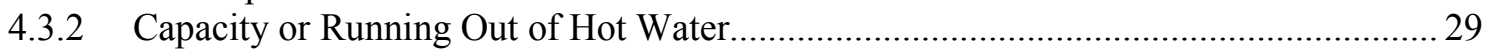

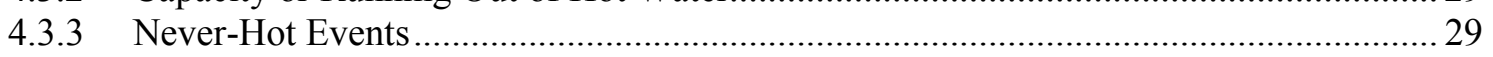

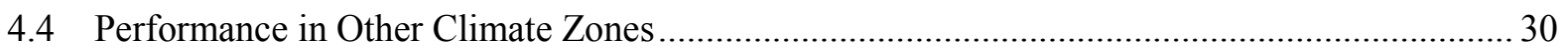

4.5 Comparing Advanced Water Heater Efficiency ................................................................... 32

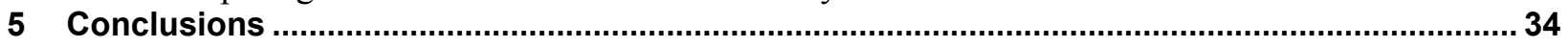

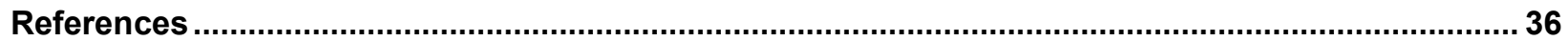




\title{
List of Figures
}

Figure 1. Comparing the efficiency of hybrid water heaters designed for retrofit with other high-efficiency gas water heaters

\author{
$\mathrm{X}$
}

Figure 2. Hybrid water heaters designed for retrofit applications

Figure 3. Monitoring equipment installed at each site

Figure 4. Inlet water temperature measured and modeled data at Site 2 .................................................. 9

Figure 5. Average domestic water heating load by inlet water temperature for Site 1 ............................. 10

Figure 6. Input versus output relationship for the hybrid water heater (WH 1) at Site 1....................... 11

Figure 7. Outlet water temperature traces for all hot water events at Site 1 with WH 1 ....................... 12

Figure 8. Mains water temperature profiles modeled on field data for each site .................................... 13

Figure 9. Linear relationship between hot water load and the mains water temperature at each site ......... 14

Figure 10. Linear relationship between hot water load and the mains water temperature at Site $4 \ldots \ldots \ldots . . .15$

Figure 11. Linear relationship between natural gas input and hot water output for each of the water heaters

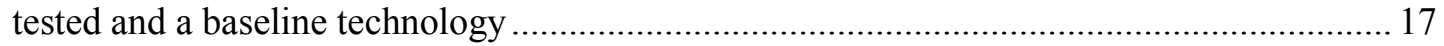

Figure 12. Regression of daily efficiency for each of the hybrid water heaters .................................... 18

Figure 13. Flow rate, outlet temperature, and electric power during a typical hot water draw .................20

Figure 14. Burner fire rate and electric power during a typical burner fire ........................................... 21

Figure 15. Daily electric consumption for each water heater .............................................................. 22

Figure 16. Outlet temperature time series plots for hot water events .................................................. 26

Figure 17. Outlet temperature time series plots for hot water events for a natural draft storage WH and a

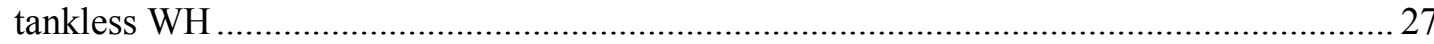

Figure 18. Fraction of draws with greater than $5 \%$ variance from set point, by time from the start of

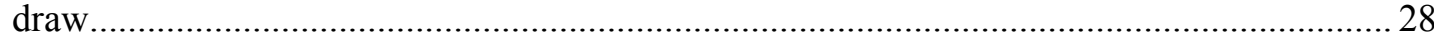

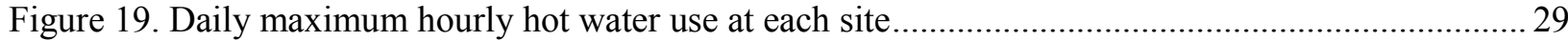

Figure 20. Fraction of draws by total length (percentage of draws shorter than $\mathrm{x}$-axis value) .................. 30

Figure 21. Comparison of the efficiency of retrofit hybrid water heaters to other high-efficiency gas water

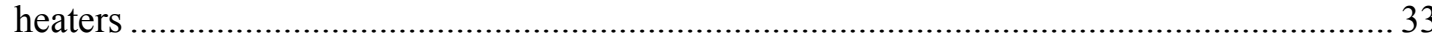




\section{List of Tables}

Table 1. Hot Water Energy Consumption Reduction for Four Retrofit Water Heaters Compared to

Minimum Efficiency Storage Water Heaters

Table 2. Water Heating Use Characteristics of Each Home ............................................................... 4

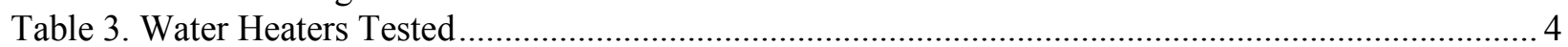

Table 4. Mains Inlet Water Temperature Conditions for Each Site.......................................................... 14

Table 5. Hot Water Load versus Main Water Temperature Characteristics ............................................ 15

Table 6. Water Heater Natural Gas Input versus Output Relationship Characteristics ........................... 16

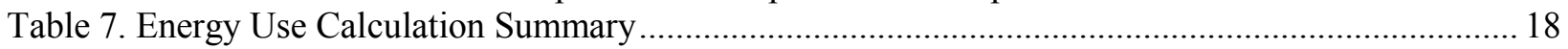

Table 8. Water Heater Electric Consumption Linear Model Parameters.................................................. 22

Table 9. Annual Gas Consumption for a Range of Household Hot Water Loads ...................................... 23

Table 10. Annual Cost Savings for a Range of Household Hot Water Loads ........................................... 23

Table 11. Equipment and Install Costs for Retrofit Hybrid Water Heaters ............................................. 24

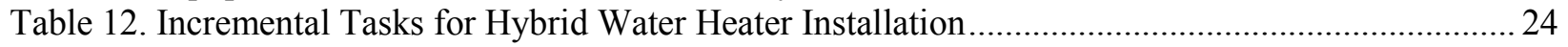

Table 13. Annual Cost Savings and Simple Paybacks....................................................................25

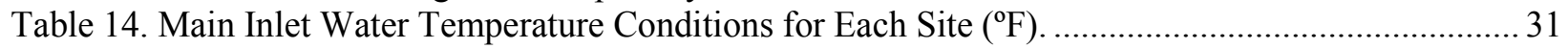

Table 15. Natural Gas Usage for Hybrid Water Heaters Under Medium Load in Various Climates......... 32 


\section{Definitions}

CStWH condensing storage water heater

CTWH condensing tankless water heater

DHW domestic hot water

EF energy factor

gal gallon

gpd gallons per day

gph gallons per hour

gpm gallons per minute

ND StWH natural draft storage water heater

RTD resistance temperature detector

StWH storage water heater

TMY3 Typical Meteorological Year 3

TWH tankless water heater

W.C. water column

WH water heater 


\section{Executive Summary}

Water heating is the second largest end use of natural gas in homes in the United States, accounting for $24 \%$ of residential use (D\&R International 2006). Water heating is also typically one of the least efficient end uses - the federal minimum efficiency (energy factor, or EF) is 0.59 for a typical 40-gal. water heater. Therefore, more efficient water heating technology has the potential to provide large natural gas savings. High-performance water heaters are typically more time consuming and costly to install in retrofit applications (National Renewable Energy Laboratory 2014), making high-performance water heaters difficult to justify economically. However, recent advancements in high-performance water heaters have targeted the retrofit market, simplifying installations and reducing costs.

Several manufacturers have developed systems to target the high-efficiency retrofit market. These manufacturers have performed extensive laboratory testing, but they are typically unable to conduct fully-monitored field tests under real occupant loads. Field-testing can demonstrate real-world potential and performance as well as show that a product meets the need for a retrofit condensing gas water heater. Field tests can also be used to identify comfort issues or to demonstrate that any comfort issues were successfully addressed for a given product.

The U.S. Department of Energy's Building America team NorthernSTAR has worked with one of these manufacturers on past projects, and the manufacturer was interested in having NorthernSTAR conduct field tests on their newest equipment. Four high-efficiency natural gas water heaters (WH 1, 2, 3, and 4, shown in Table 1) designed specifically for retrofit applications were installed in single-family homes along with detailed monitoring systems to characterize their savings potential, installed efficiencies, and abilities to meet household demands.

To be considered for this project, each water heater was required to have a combination of a high input, energy-efficient gas burner, some hot water storage capacity, and compatibility with a $1 / 2$ in. gas line. The project assessed the impact of smaller gas lines on the overall cost-effectiveness of the installed units. Field data were also used to analyze the impact on hot water quality, especially the benefits of hot water storage (such as reduced cold water sandwich, delay until hot, and low-flow performance), and the impact of the reduced gas line on capacity.

The water heaters tested for this project were designed to improve the cost-effectiveness and increase market penetration of high-efficiency water heaters in the residential retrofit market. The retrofit high-efficiency water heaters achieved their goal of reducing costs, maintaining savings potential and installed efficiencies compared to other high-efficiency water heaters (Table 1 and Figure 1), and meeting the necessary capacity to improve cost-effectiveness. However, the improvements were not sufficient to achieve simple paybacks of less than 10 years for the incremental cost compared to a minimum-efficiency heater. In most cases the paybacks were as long as or longer than the expected lifetime of the water heater (12 to 20 years). Significant changes would be necessary to reduce the simple payback to 6 years or less.

- Incremental costs less than $\$ 400$ would have paybacks of 6 years but would require a large reduction in the water heater equipment cost or a change in the baseline water heater installation. 
- Annual energy savings in the range of $\$ 200$ would also reduce paybacks to less than 6 years, but these energy savings would require either significantly higher fuel costs (greater than $\$ 1.50$ per therm) or very high usage (around 120 gal. per day [gpd]).

- For current incremental costs, the water heater would need an efficiency in excess of $200 \%$ to deliver a 6 -year payback.

Table 1. Hot Water Energy Consumption Reduction for Four Retrofit Water Heaters Compared to Minimum Efficiency Storage Water Heaters

\begin{tabular}{l|l|l|l|l|l}
\hline & \multirow{2}{*}{$\begin{array}{l}\text { Hot Water } \\
\text { Use (gpd) }\end{array}$} & \multicolumn{4}{|c}{ Annual Natural Gas Savings (\%) } \\
\cline { 3 - 6 } & WH 1 & WH 2 & WH 3 & WH 4 \\
\hline Very Small & 10 & $48 \%$ & $42 \%$ & $60 \%$ & $50 \%$ \\
\hline Low Usage & 38 & $38 \%$ & $27 \%$ & $45 \%$ & $37 \%$ \\
\hline Medium & 55 & $35 \%$ & $24 \%$ & $41 \%$ & $34 \%$ \\
\hline High Usage & 84 & $33 \%$ & $21 \%$ & $38 \%$ & $31 \%$ \\
\hline
\end{tabular}

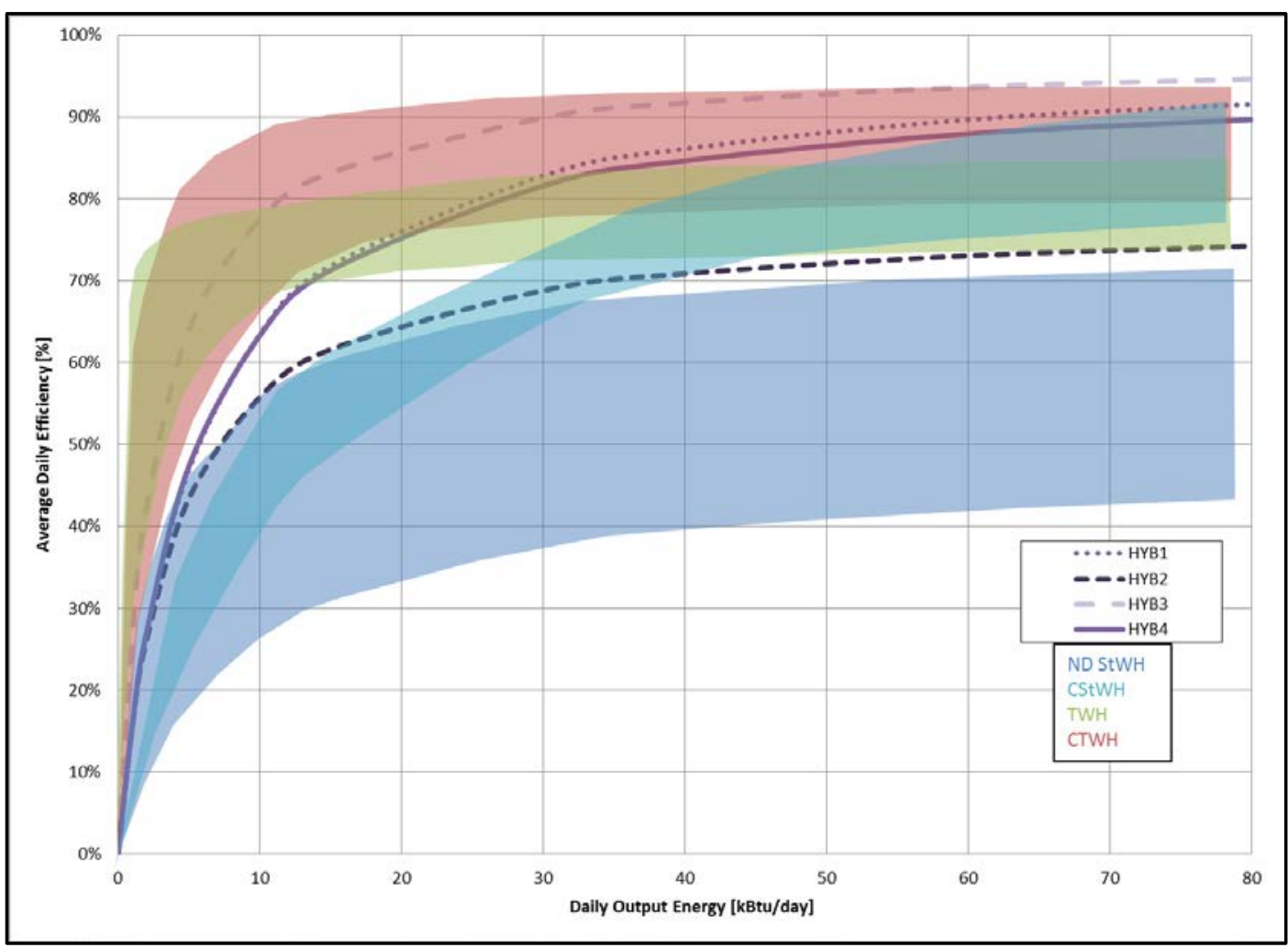

Figure 1. Comparing the efficiency of hybrid water heaters designed for retrofit with other highefficiency gas water heaters 


\section{Introduction}

Water heating is the second largest end use of natural gas in homes in the United States, accounting for $24 \%$ of residential use (D\&R International 2006). Water heating is typically one of the least efficient end uses - the federal minimum efficiency (energy factor, or EF) is 0.59 for a typical 40-gal. water heater manufactured before April 2015 and 0.615 for a similar water heater installed after April 2015. Therefore, more efficient water heating technology has the potential to provide large natural gas savings. High-performance water heaters are more time consuming and costly to install in retrofit applications (National Renewable Energy Laboratory 2014), making high-performance water heaters difficult to justify economically. However, recent advancements in high-performance water heaters have targeted the retrofit market, simplifying installations and reducing costs.

\subsection{Background}

Recent field-monitoring projects have demonstrated significant savings resulting from the performance of natural gas tankless and high-efficiency storage water heaters. The Center for Energy and Environment installed both a new natural draft storage water heater and one or two tankless units into 10 homes in Minnesota (Bohac et al. 2010). The active water heater, either the storage water heater or the tankless, was alternated during a 12-month monitoring period while performance data were collected. The data were then compared to determine annual energy savings, installed efficiencies, and water delivery capabilities. The Davis Energy Group conducted a pre-/post-installation field study to monitor the performance of natural gas natural draft storage water heaters, power vent storage water heaters, gas tankless water heaters, and condensing storage water heaters (Hoeschele 2012). Both of these studies showed significant energy savings for condensing tankless water heaters, but despite substantial savings, system paybacks were long due to high installation costs for many retrofit applications. The necessity to increase gas line size in the homes often added to these costs. Eliminating that portion of the installation cost would reduce the system payback time and likely increase market penetration.

Both the Davis Energy Group study and the NorthernSTAR team's combined space and water heating research have shown that high standby losses in condensing water heaters with hot water storage can significantly reduce performance. Laboratory testing by NorthernSTAR has shown that these higher standby losses occur with smaller poorly insulated tanks or larger well-insulated tanks. Improved insulation, smaller storage volumes, and controls are likely the most effective solutions to reducing energy losses and improving performance.

The majority of residential water heaters are sold for retrofit or replacement applications. Water heater retrofits provide an opportunity to significantly improve energy efficiency and reduce energy use. Field research has demonstrated savings potential of $30 \%$ to $40 \%$ of the natural gas consumption of water heaters; however, existing heaters are most often replaced when the existing heater fails, and condensing gas water heaters are typically not considered in this situation due to associated installation challenges and high cost. This is due in part to the fact that many high-efficiency products (such as condensing tankless water heaters) require larger gas lines. A high-efficiency unit capable of operation on a $1 / 2$-in. gas line would reduce the installation difficulty and cost and increase high-efficiency water heating implementation. 
Several manufacturers have developed systems to target the high-efficiency retrofit market. These manufacturers have performed extensive laboratory testing, but they are typically unable to conduct fully-monitored field tests under actual occupant loads. Field-testing can demonstrate real-world potential and performance as well as show that the product meets the need for a retrofit condensing gas water heater. Field tests can also be used to identify comfort issues or to demonstrate that any comfort issues were successfully addressed for a given product. The U.S. Department of Energy Building America team NorthernSTAR worked with one of these manufacturers on past projects, and the manufacturer was interested in having NorthernSTAR conduct field tests on their newest equipment.

\subsection{Relevance to Building America's Goals}

In the 2013 Building America Critical Path report (National Renewable Energy Laboratory 2013), high-efficiency natural gas water heating was listed as a priority. Specifically, Building America identified the need for high-efficiency closed-combustion gas water heaters that utilize existing home gas infrastructure and have high efficiency. The goal was to help manufacturers recognize the profitability of the high-efficiency retrofit gas water heating market, develop products for that market, and characterize the products' performance in the field. This project will provide a characterization of these high-efficiency products in real homes. 


\section{Experiment}

Four high-efficiency natural gas water heaters (WH 1, 2, 3, and 4) designed specifically for retrofit applications were installed in single-family homes along with detailed monitoring systems to characterize their savings potential, their installed efficiencies, and their ability to meet household demands. To be considered for this project each water heater was required to have a combination of high input, an energy-efficient gas burner, some hot water storage capacity, and compatibility with a $1 \frac{1}{2}$-in. gas line. The project assessed the impact of smaller gas lines on the overall cost-effectiveness of the installed units. Field data were also used to analyze the impact on hot water delivery quality, especially the benefits of hot water storage (such as reduced cold water sandwich, delay until hot, and low flow performance), and the impact of the reduced gas line on capacity.

\subsection{Research Questions}

The following research questions were posed in this water heater retrofit project:

- How much impact do lower input burners with smaller gas line sizing requirements have on installation costs and water heater economics in retrofit applications of condensing gas water heaters?

- What are the installed efficiencies of these new condensing gas water heaters?

- Can water heaters with lower input rates meet the loads of typical residential homes?

- Have newer units solved the slower ramp up time and inconsistency with staged event comfort issues exhibited by early model tankless water heaters?

\subsection{Test Sites}

Test sites were selected based on the feasibility of water heater installation and expected household load. Five homes were considered for the four water heater installations. One of the five homes was excluded due to installation considerations. The project contractor noted that high-efficiency burner venting issues typically exclude 1 in 5 to 1 in 10 homes. The house excluded from this project had at least one feasible installation option and had either interior space or exterior aesthetic concerns that prevented venting installation. The NorthernSTAR team's past experiences with high-efficiency equipment confirm the contractor's observations. Water heater sizing guidelines were also considered for site selection. The number of occupants and shower fixtures were matched to the water heater manufacturer's recommendations for their unit (Table 2). 
Table 2. Water Heating Use Characteristics of Each Home

\begin{tabular}{l|l|l|l}
\hline Site & $\begin{array}{l}\text { Number of } \\
\text { Occupants }\end{array}$ & $\begin{array}{l}\text { Occupant } \\
\text { Ages }\end{array}$ & $\begin{array}{l}\text { Number of } \\
\text { Showers/Tubs }\end{array}$ \\
\hline 1 & 2 & 20 to 30 & 2 \\
\hline 2 & 2 & 30 to 40 & 2 \\
3 & 3 & 20 to 30 & 2 \\
\hline 4 & 2 & 20 to 30 & 2 \\
\hline
\end{tabular}

\subsection{Systems}

Traditional tankless water heaters have no dedicated storage capacity and limited water volume within the water heater. These units rely on high burner input rates (typically $150,000 \mathrm{Btu} / \mathrm{h}$ or more) and burner modulation to meet the heating capacity needed in real time. Traditional storage water heaters store a large volume of hot water (typically 40 gal. or greater) that is periodically heated by a smaller burner (approximately 40,000 Btu/h). All of the water heaters tested for this project were hybrid models that combined a high-efficiency tankless water heater burner with some amount of storage capacity.

In 2014 an increasing number of water heater manufacturers released hybrid water heaters. The intent of these products was to target high-efficiency gas water heater retrofit applications. The approach combined the increased efficiency and reduced size of tankless water heaters with the storage capacity of storage water heaters. In addition to reducing delay times and eliminating minimum flow rate requirements, the extra storage capacity allows for a smaller burner with input rates achievable with a standard gas line size ( $1 / 2$ in.) and pressure (5 to $10-1 / 2-i n$. water column [W.C.]). For this project, four water heaters were selected (Table 3 ) to be representative of the different design approaches used to combine features into hybrid water heaters. These approaches are defined by burner design, water heater input rating, and the amount of storage capacity.

Table 3. Water Heaters Tested

\begin{tabular}{l|r|r|r|r|r|r|r}
\hline Manufacturer & WH \# & EF & $\begin{array}{r}\text { Thermal } \\
\text { Efficiency }\end{array}$ & $\begin{array}{r}\text { Firing } \\
\text { Rate } \\
\text { (kBtu/h) }\end{array}$ & $\begin{array}{r}\text { Storage } \\
\text { Volume } \\
\text { (gal) }\end{array}$ & $\begin{array}{r}\text { Max } \\
\text { Flow } \\
\text { (gpm) }\end{array}$ & $\begin{array}{r}\text { First } \\
\text { Hour } \\
\text { Rating }\end{array}$ \\
\hline Grand Hall - GU120 & 1 & 0.94 & N/A & 18 to 120 & 2.0 & 2.8 & N/A \\
\hline Rinnai - RH180 & 2 & N/A & $80 \%$ & 60 to 91 & 40.0 & N/A & 180 \\
\hline Navien - NPE-180A & 3 & 0.97 & N/A & 15 to 150 & 0.5 & 3.8 & N/A \\
\hline Grand Hall - T-series & 4 & N/A & $96 \%$ & 100 & 20.0 & N/A & 160 \\
\hline
\end{tabular}

Each of the four water heaters uses a different combination of storage capacity, heat transfer method, burner capacity, and burner modulation to achieve acceptable performance.

- WH 1 has a 2-gal. hot water storage tank that is maintained by a modulating 18,000 to $120,000 \mathrm{Btu} / \mathrm{h}$ burner. Heat is transferred from the burner to the storage tank through a heat exchanger that is integrated within the walls of the storage tank. 
- WH 2 has a 60,000 to 91,000 Btu/h modulating burner and a 40-gal. hot water storage tank. This water heater is a hybrid of a noncondensing tankless water heater and storage tank. It uses a less efficient burner than the other hybrid water heaters included in this study, which allows the installer to reuse the exiting b-vent exhaust venting and significantly reduces install time and costs.

- WH 3 uses a negative pressure gas valve and the venturi effect for flow control to a 15,000 to $150,000 \mathrm{Btu} / \mathrm{h}$ modulating gas burner. The additional input capacity of this burner design allows this model to operate on a $1 / 2$-in. gas line with only $1 / 2$ gal. of hot water storage.

- WH 4 uses a fixed 100,000 Btu/h burner with 20 gal. of hot water storage.

A picture of each unit is displayed in Figure 2.
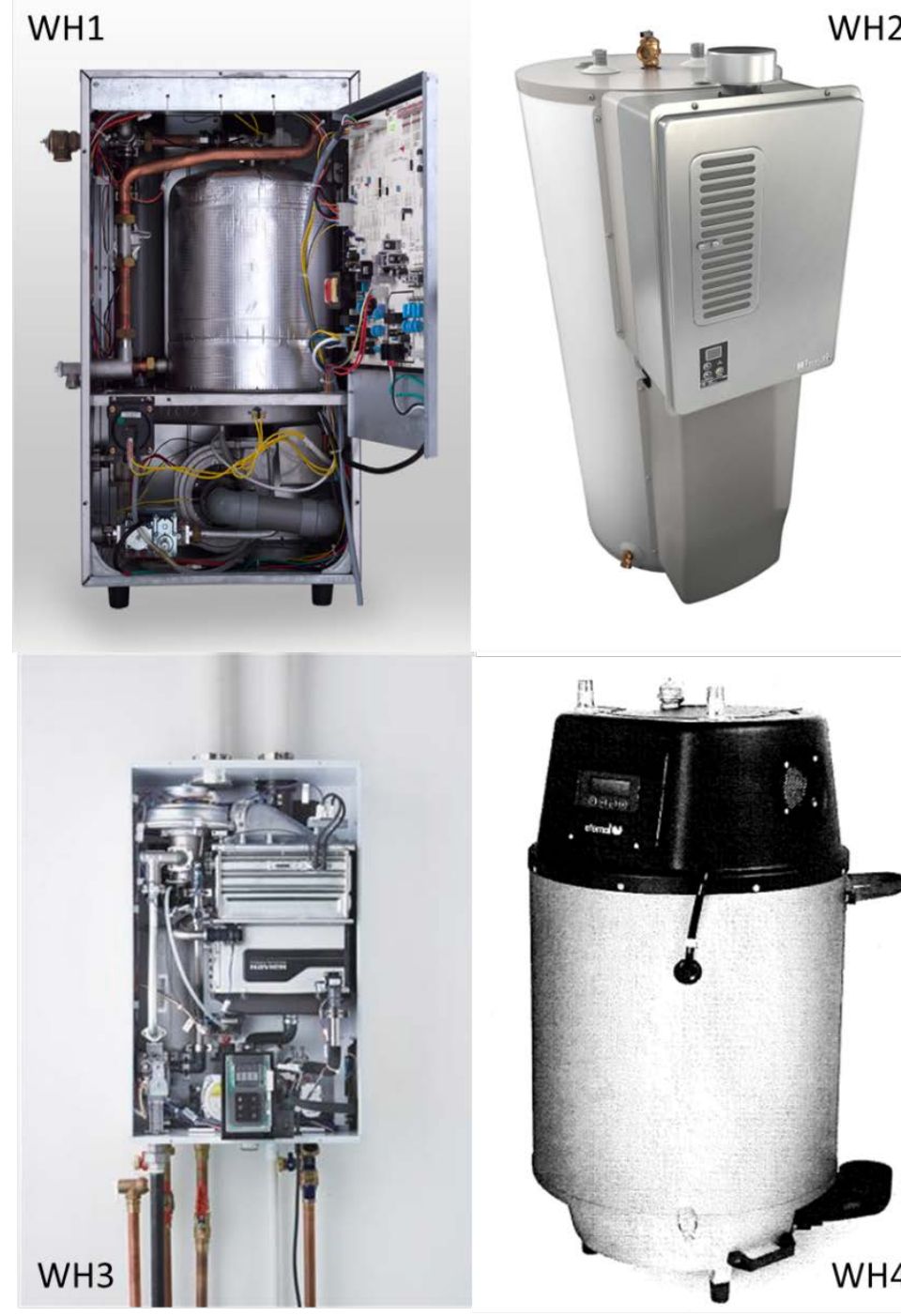

Figure 2. Hybrid water heaters designed for retrofit applications 


\subsection{Measurements}

Figure 3 shows the monitoring equipment installed with each water heater. Data were collected and stored at 1-second intervals. The monitoring equipment included:

- A hot water flow meter located at the inlet of the water heater with a resolution of 0.005 gal. per pulse (198.4 pulses per gal) and an accuracy of $1.5 \%$.

- An inlet and outlet immersion resistance temperature detector (RTD) installed 6 in. from the inlet and outlet of the water heater. These devices were installed in baseboard tees to ensure accurate placement. The RTDs were paired and have $\pm 0.1^{\circ} \mathrm{F}$ accuracy.

- A gas meter on the water heater gas line. These were residential diaphragm meters with pulse transducers installed on the dials. The meter provides $1.5 \%$ accuracy and $0.025 \mathrm{ft}^{3}$ per pulse (40 pulses per $\mathrm{ft}^{3}$ ) resolution.

- A watt transducer to measure the electrical consumption. It was installed on the power plug of each water heater. The watt transducers have an accuracy rating of $0.5 \%$.

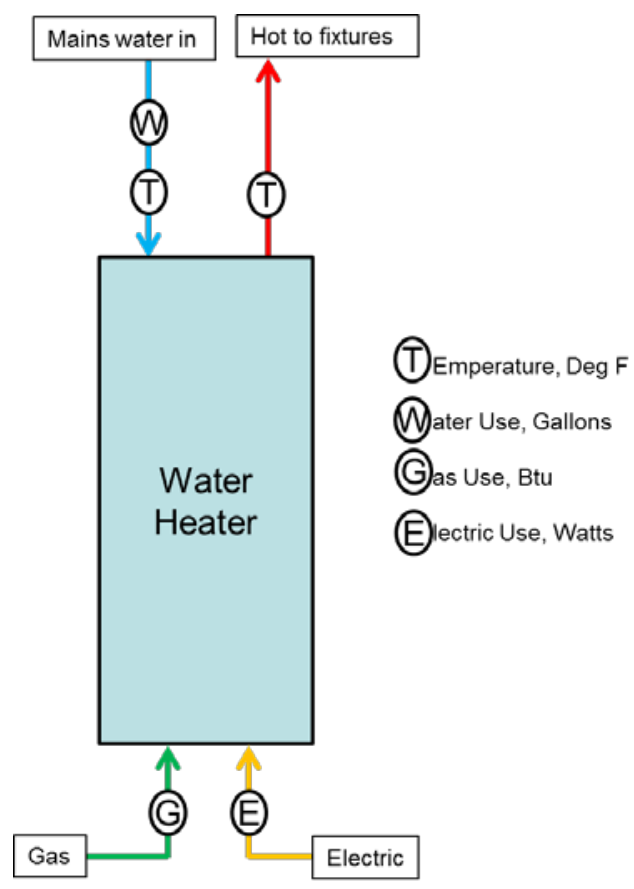

Figure 3. Monitoring equipment installed at each site

\subsection{Monitoring}

Each site had a single new high-efficiency water heater installed, along with a detailed instrumentation package. Data were collected for at least 10 months at each site. The monitoring package and data collection period was designed to fully characterize the water heater performance over the wide range of hot water usage patterns and the seasonal effects of main water temperature and occupant behavior.

The savings potential and installed efficiency were assessed for each water heater. A linear input/output methodology was used to determine the annual installed energy use and efficiency 
of each water heater. This methodology has been successfully used by this research team on several types of systems such as commercial boilers, both storage and tankless water heaters, and combined space and water heating systems (Bohac et al. 2010; Schoenbauer 2012).

The daily water usage data were collected at each site in this study as well as previous gas water heating projects. The usage data were used to compare the performance of these new highefficiency retrofit water heaters to previously monitored water heaters such as a natural draft storage baseline, noncondensing tankless, condensing tankless (Bohac et al. 2010), and condensing storage water heaters (Schoenbauer 2012).

The capacity and ability of each water heater to meet load was also assessed. One-second interval outlet water temperature data were used to determine the ability of the water heaters to meet the domestic hot water (DHW) load. The data were analyzed to evaluate three hot water delivery capability metrics: (1) the hot water delivery time, determining how long it took for the unit to deliver stable hot water, (2) the ability to meet high load demands (i.e., the potential for running out of hot water), and (3) the frequency of brief hot water events where the water heater did not deliver any hot water. 


\section{Analysis}

This section details the annual water heater energy consumption analysis and the delivered quality of hot water in each of the four test water heaters,

\subsection{Annual Energy Use}

The annual energy consumption of the water heaters was calculated through a combination of directly measured data, analysis, and regression statistics. This approach was necessary due to the seasonality of hot water use and the differences between weather conditions during the monitoring periods for different water heaters. Seasonal weather conditions impact hot water use and hot water energy consumption at many homes. The hybrid water heaters tested for this project were not measured for a full year and their performance was compared to baseline water heaters measured in a previous year. Measured data were used to create regression models in order to calculate the annual performance and compare to the performance of a baseline water heater under the same weather conditions.

A four-step process was used to compute the annual DHW energy use based on inlet water temperatures, DHW demand models, and appliance efficiency models.

\subsubsection{Seasonal Variation and Annual Average Inlet Water Temperature}

For the first step, a model was developed for inlet (or mains) water temperature to establish the seasonal variation and annual average inlet water temperature. The inlet temperature has been found to have a sinusoidal relationship with day of the year (Burch and Christensen 2007). The inlet temperature model parameters are functions of the average outside air temperature, time lag from the outside air temperature, and difference in the maximum and minimum average monthly temperatures.

The model parameters were fit to the measured field data at each site. Mains water temperature was determined from the immersion temperature sensor at the water heater inlet, averaging the water temperatures after the first 5 minutes of hot water events longer than 5 minutes. The 5 minute buffer period eliminated any impact of heat transfer from the home into water in the distribution system. Days that did not have at least one 5-minute draw were not included in the analysis.

Figure 4 shows the measured and modeled weekly inlet water temperatures at Site 2 . The sitespecific mains temperature model was used to calculate the annual average mains temperature for each site. Using the modeled mains data allowed for an average annual temperature that represented a full year without missing data. 


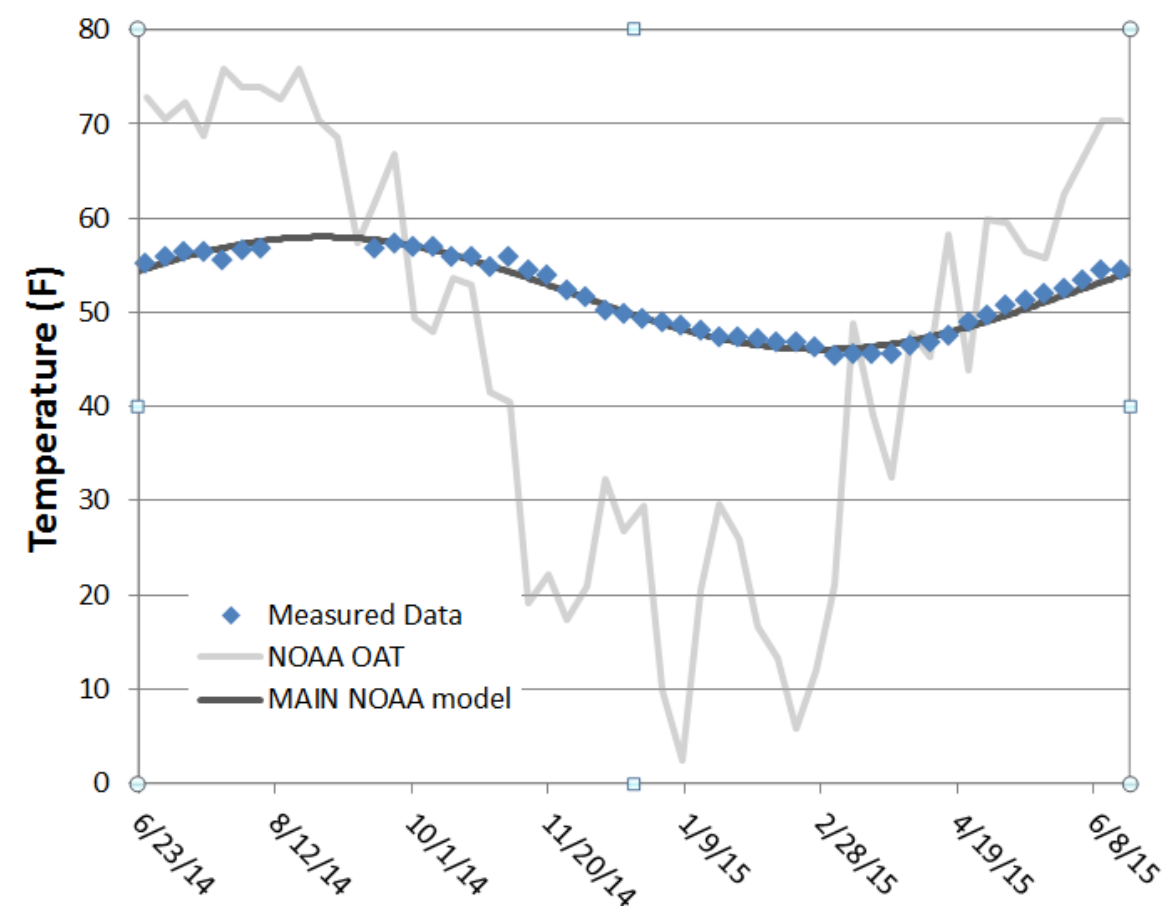

Figure 4. Inlet water temperature measured and modeled data at Site 2

\subsubsection{Inlet Water Temperature and Domestic Hot Water Demand}

The second step was to develop a linear relationship between the inlet water temperature and DHW output or demand (i.e., the energy delivered by the water heater in hot water, AKA Qout) (Equation 1). This relationship characterized the seasonality of the hot water demand for a home. Previous studies have shown that a high fraction of the houses in Minnesota have a statistically significant DHW load seasonality. The primary cause of the lack of seasonality was a limited range of mains water temperatures. For example, homes with on-site wells may have as little as $3^{\circ} \mathrm{F}$ mains temperature variance over the year.

Due to the high variance in the daily water usage the relationships were developed using weekly averaged data. Weekly averages have less variance, as water usage patterns often differ on weekdays and weekends. Additionally, hot water loads such as dishwashers and clothes washers operate on more of a weekly than daily schedule. Figure 5 shows the inlet water temperature and hot water demand relationship for Site 1.

$$
\begin{aligned}
& \text { Output }=m_{\text {seas }} T_{\text {mains }}+b_{\text {seas }} \\
& \text { Output = daily hot water output energy (Btu) } \\
& \mathrm{m}_{\text {seas }}=\text { slope from the linear regression } \\
& \mathrm{T}_{\text {mains }}=\text { main water temperature }(\mathrm{F}) \\
& \mathrm{b}_{\text {seas }}=\text { intercept from the linear regression. }
\end{aligned}
$$




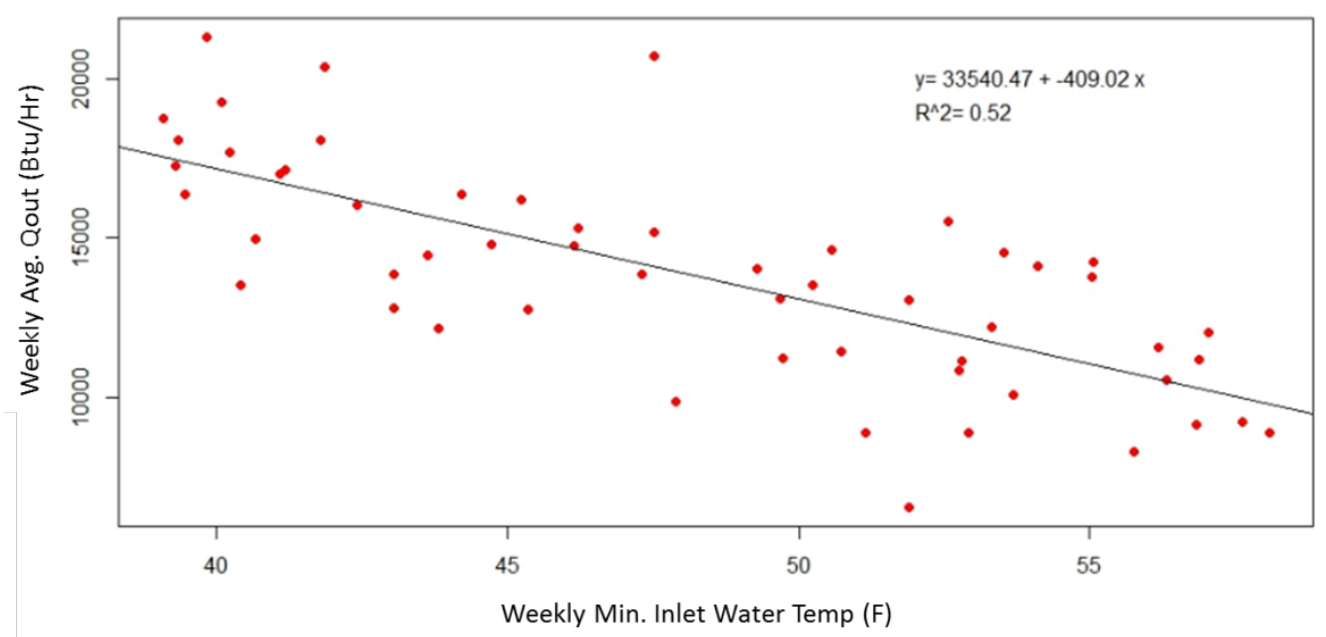

Figure 5. Average domestic water heating load by inlet water temperature for Site 1

\subsubsection{Water Heater Energy Use}

The third step was to compute the water heater energy use (aka, input). Measured daily average energy use and DHW load data were fit to linear model for each water heater (Equation 2). The model or water heater performance map characterized the energy usage and delivery capabilities of each water heater. The average DHW load, computed in steps one and two, was used with this linear model to determine the average energy use for each water heater. These appliance energy use models were very well defined; each model had R-squared values higher than 0.95 .

$$
\begin{aligned}
& \text { Input }=m_{w h} \text { Output }+b_{w h}(2) \\
& \text { Input = daily gas consumption (Btu) } \\
& \mathrm{M}_{\mathrm{wh}}=\text { slope from the input output linear regression } \\
& \text { Output = daily hot water output energy (Btu) } \\
& \mathrm{b}_{\text {seas }} \text { intercept from the input output linear regression. }
\end{aligned}
$$

Each of the homes in this study had a natural draft minimum-efficiency (an average EF of 0.58) gas water heater prior to the study. These water heaters are representative of the baseline water heater for homes with natural gas. The performance of this type of baseline water heater has been thoroughly monitored in past studies and therefore was not monitored for this project. The results for eight identical 0.60 EF, 40-gal, natural draft storage water heaters (Schoenbauer et al. 2011) were used as the baseline. The models' fit to the data from the eight baseline water heaters was consistent: At a daily hot water demand of $30,000 \mathrm{Btu} / \mathrm{h}$ (about 50 gal. at a $70^{\circ} \mathrm{F}$ temperature rise) the modeled input rates varied by only $7 \%$. The previously studied baseline water heaters were newly installed and had a slightly higher EF rating than the water heaters replaced for this study, which may reduce the savings estimates slightly $(<2 \%)$. 


\subsubsection{Calculating Annual Domestic Hot Water Energy Use}

The final step in the annual energy use calculation process combined each of the three models (Equation 3). First, the seasonal inlet water temperature model (Figure 4) was used to determine the annual average inlet water conditions for the home. Second, the average inlet water temperature was used with the DHW load seasonality (Figure 5) model to determine the average daily hot water load. Finally, the average hot water load was used to determine the daily average energy consumption from the appliance energy use model (Figure 6). The mains temperatures to load and load to input models are linear. Because the two models are linear the annual average mains temperature could be used with the models to calculate the annual savings and it was not necessary to conduct the analysis using daily values.

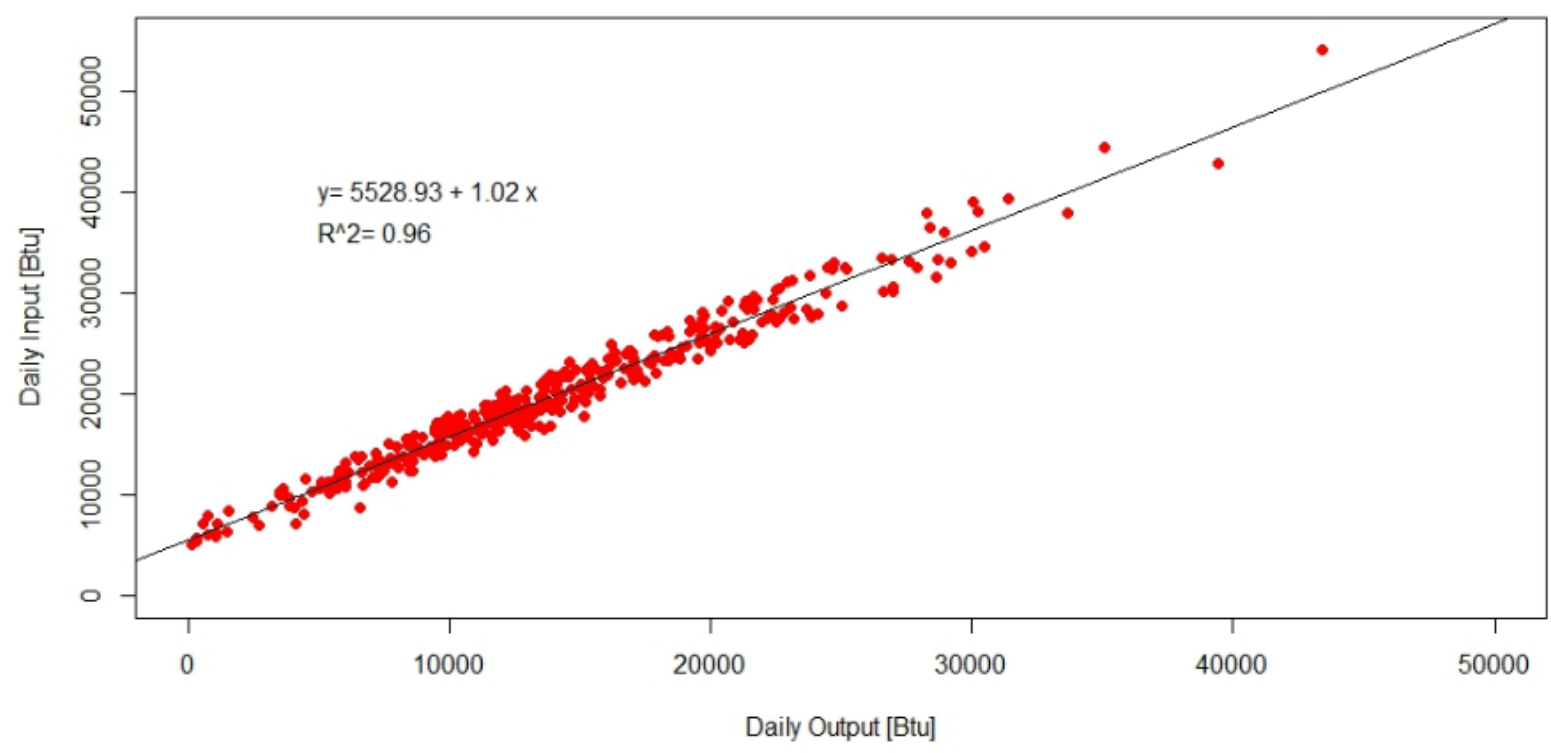

Figure 6. Input versus output relationship for the hybrid water heater (WH 1) at Site 1

$$
\text { Annual Enegy Use }=\left(m_{w h}\left(m_{\text {seas }}(\text { Annual Mains })+b_{\text {seas }}\right)+b_{w h}\right)
$$

\subsection{Delivered Quality}

In addition to energy use and savings data, the measured field data were used to access the hot water delivery quality of each of the water heaters. The 1-second interval data of outlet temperature of each water heater during periods of active hot water use were used to evaluate the water heater delivery quality. Three delivery categories were examined to characterize areas of delivered quality and potential user complaints: 1) start-up temperatures and delay times; 2) water heater capacity, or running out of hot water; and 3) hot water events for which hot water was never produced. Each of these categories was assessed by analyzing the outlet temperature or the home's usage compared to the water heater capacity. Analysis included determining outlet temperature traces for each hot water event (Figure 7), calculating hourly usage rates for capacity sizing, and counting draw events based on delivered water temperatures. 


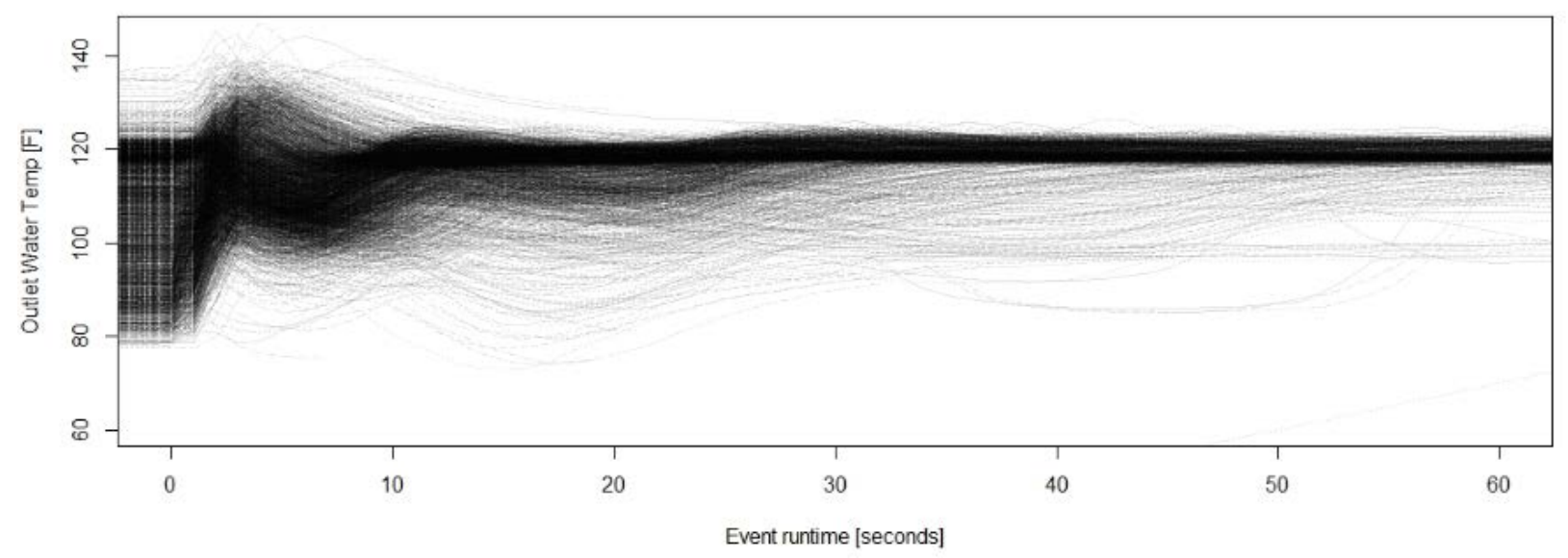

Figure 7. Outlet water temperature traces for all hot water events at Site 1 with WH 1 


\section{Results}

The results of the retrofit hybrid water heater analyses are as follows.

\subsection{Energy Consumption}

As described in Section 3, the annual water heater energy use can be computed from mains profile, the DHW load seasonality relationship, and the water heater performance regression. Each of these models and regressions were computed for all four water heaters and test homes.

Main water temperature data were collected at each home for at least a 10-month period. These data were used to create the mains temperature model for each site (Figure 8). The average annual mains temperatures for each site ranged from $49^{\circ} \mathrm{F}$ to $54^{\circ} \mathrm{F}$. This variance was due to the different water sources, treatment, and distribution systems in different areas of the Minneapolis/St. Paul metro area. Table 4 shows the city and water source for each site. Surface water sources, like the Mississippi River at Site 3, have greater temperature variance over a year than ground water sources. Mains water from city wells also had a large degree of seasonality. The original source water from the wells likely had only small seasonality, but the citywide distribution and aeration during treatment adds a significant seasonality to the water temperature.

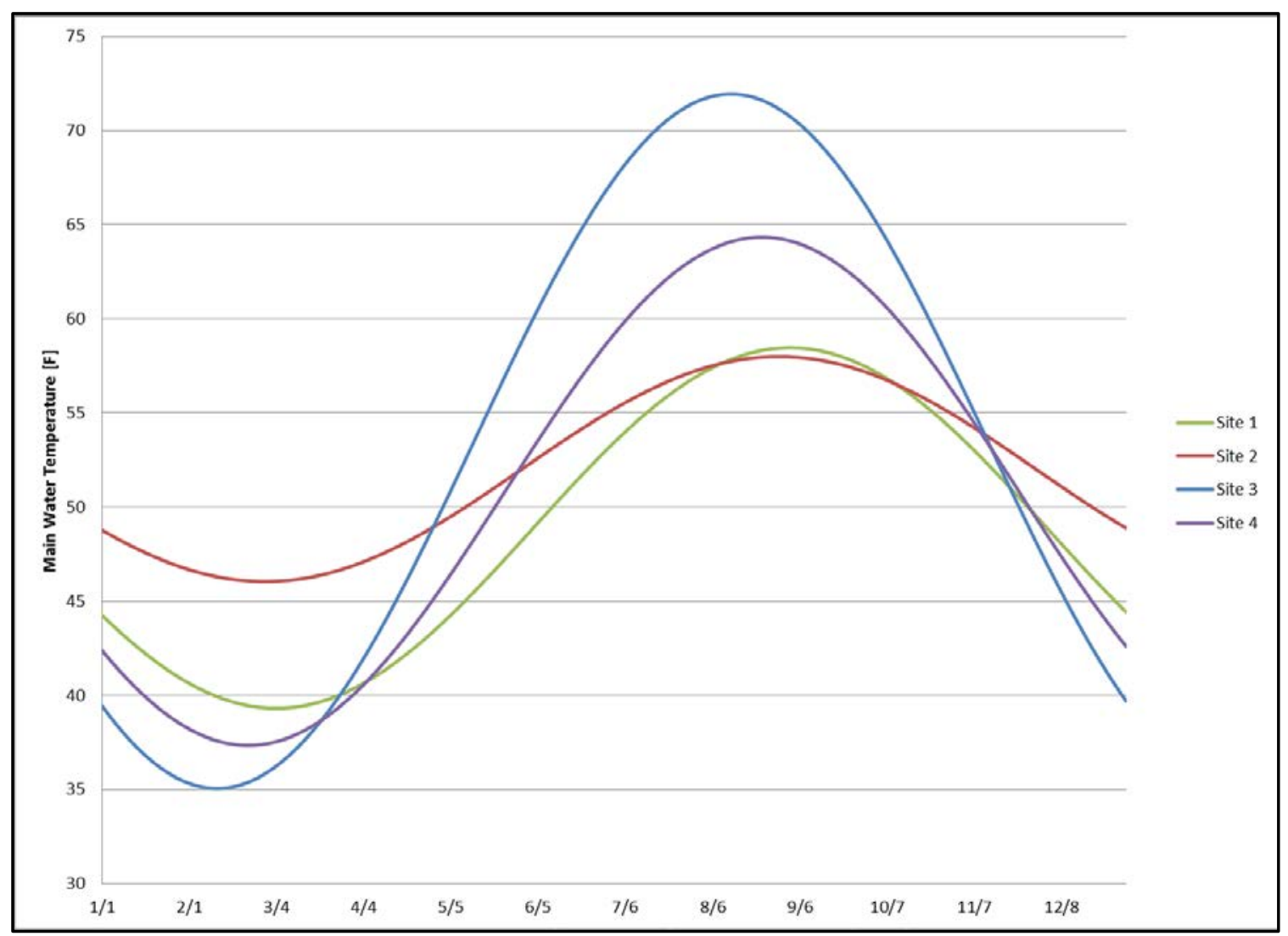

Figure 8. Mains water temperature profiles modeled on field data for each site 
Table 4. Mains Inlet Water Temperature Conditions for Each Site

\begin{tabular}{|c|c|c|c|c|c|c|}
\hline \multirow[b]{2}{*}{ Site } & \multirow[b]{2}{*}{ WH } & \multicolumn{3}{|c|}{ Mains Water Temperature $\left({ }^{\circ} \mathrm{F}\right)$} & \multirow[b]{2}{*}{ City } & \multirow[b]{2}{*}{$\begin{array}{l}\text { Water } \\
\text { Source }\end{array}$} \\
\hline & & $\begin{array}{l}\text { Annual } \\
\text { Average }\end{array}$ & $\begin{array}{l}\text { Daily } \\
\text { Minimum }\end{array}$ & $\begin{array}{l}\text { Daily } \\
\text { Maximum }\end{array}$ & & \\
\hline 1 & 1 & 49 & 39 & 58 & Maple Groove & City Well \\
\hline 2 & 2 & 54 & 35 & 72 & Minneapolis & Surface \\
\hline 3 & 3 & 51 & 37 & 64 & Minnetonka & City Well \\
\hline 4 & 4 & 52 & 46 & 58 & Bloomington & City Well \\
\hline
\end{tabular}

The DHW load was characterized at each site using the methodology discussed in the Analysis section (Section 3, Figure 9). Table 6 shows the regression parameters for each home. Site 1, Site 2 , and Site 3 were statistically significant and showed the seasonal impact of mains water temperature variance on hot water use. Site 4 had larger week-to-week variance in hot water use than other sites (Figure 11) and no seasonal significance (p-value $>0.05$ ).

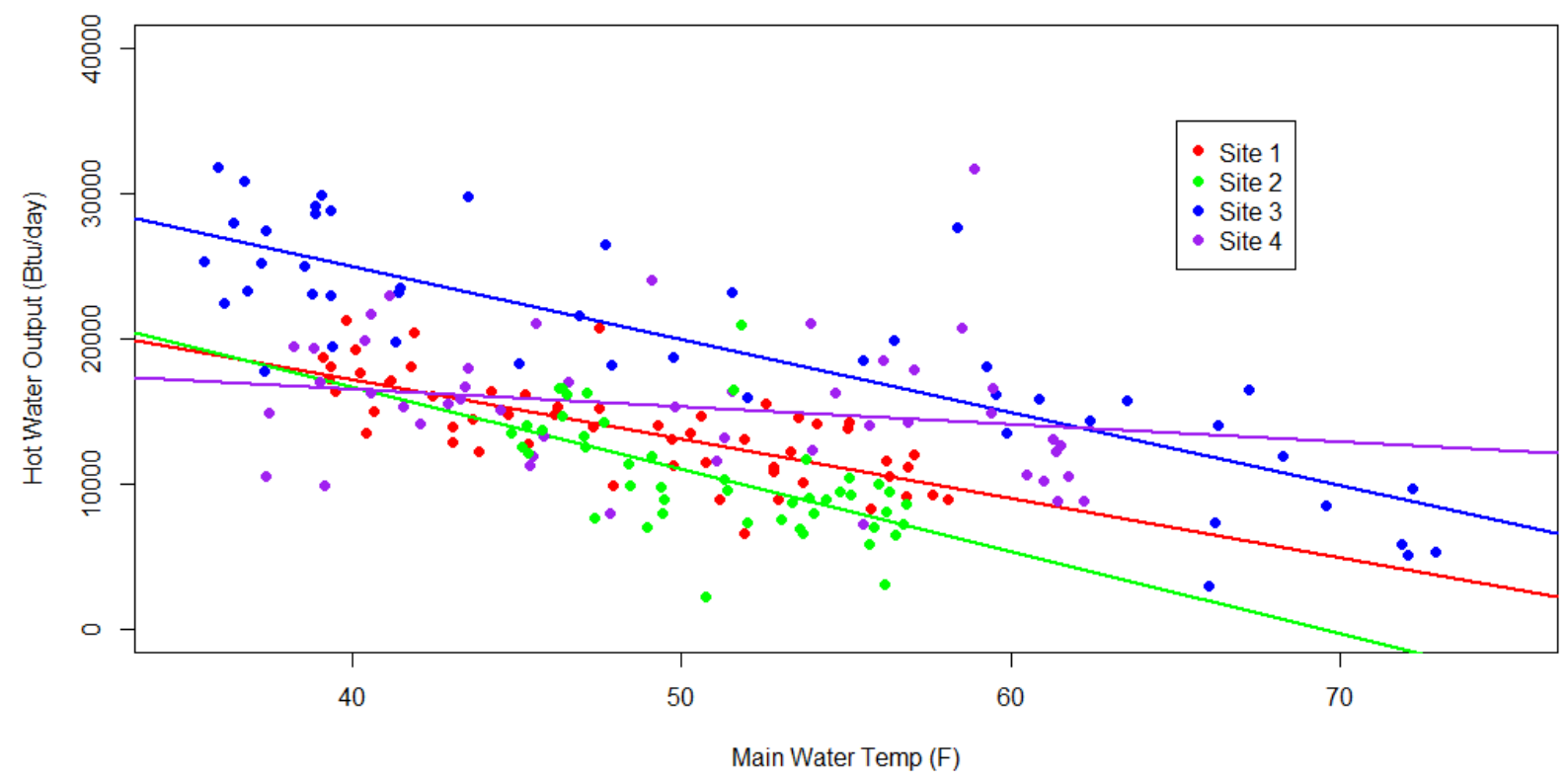

Figure 9. Linear relationship between hot water load and the mains water temperature at each site 


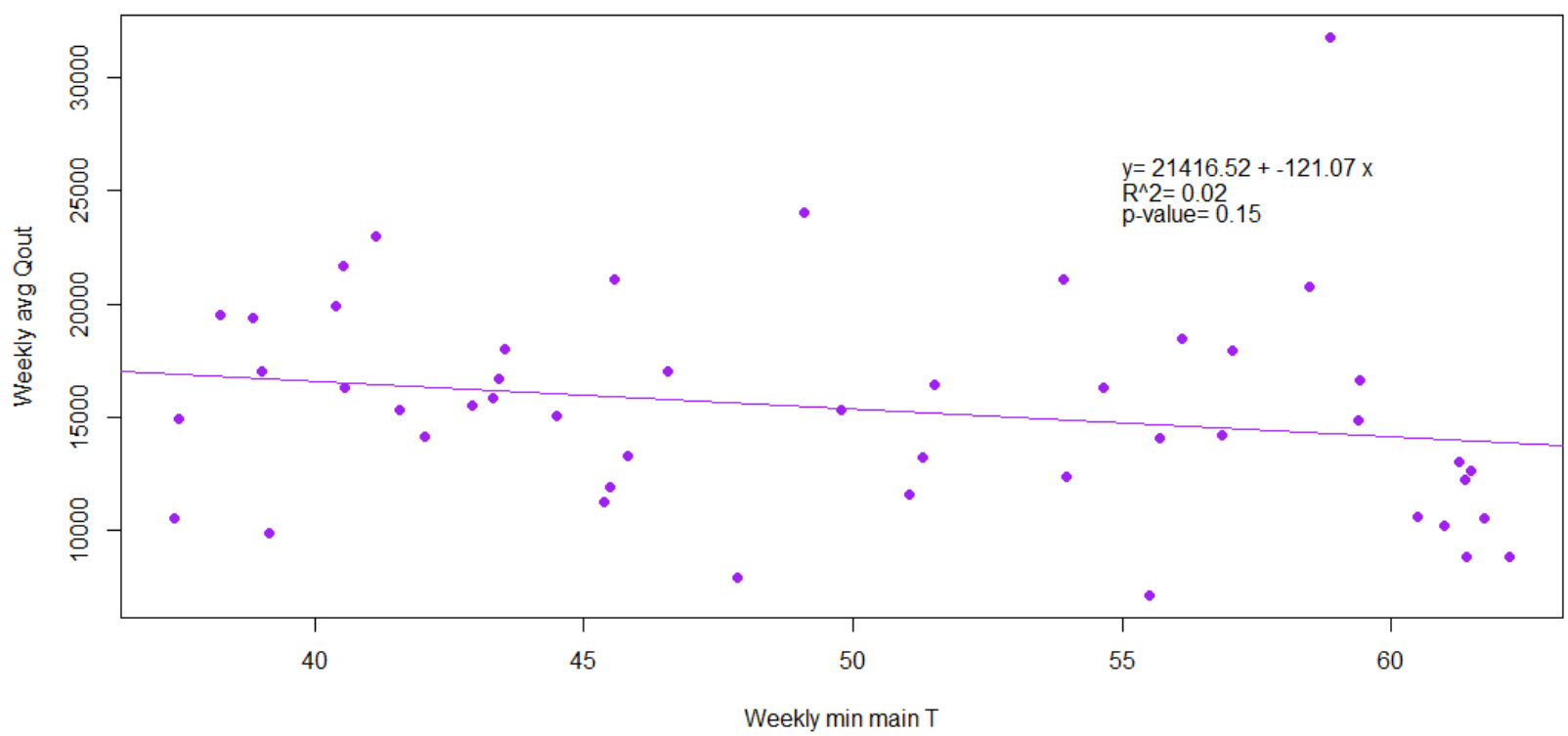

Figure 10. Linear relationship between hot water load and the mains water temperature at Site 4

Table 5. Hot Water Load versus Main Water Temperature Characteristics

\begin{tabular}{l|r|r|r|r|r|r}
\hline Site & Slope & $\begin{array}{r}\text { Intercept } \\
\text { (Btu/d) }\end{array}$ & $\mathbf{R}^{\mathbf{2}}$ & P-Value & $\begin{array}{r}\text { Statistical } \\
\text { Significance }\end{array}$ & $\begin{array}{r}\text { Annual Output } \\
\text { (Btu/d) }\end{array}$ \\
\hline 1 & -409 & 33,540 & 0.525 & $<0.001$ & Yes & 13,544 \\
\hline 2 & -569 & 39,454 & 0.331 & $<0.001$ & Yes & 9,870 \\
\hline 3 & -504 & 45,181 & 0.710 & $<0.001$ & Yes & 18,203 \\
\hline 4 & -121 & 21,417 & 0.024 & 0.147 & No & 15,177 \\
\hline
\end{tabular}

Table 5 shows the seasonal load model parameters for each site. The annual loads for Site 1, Site 2, and Site 3 were calculated using the annual mains temperature and the linear seasonal load model. Because this model was not statistically significant at Site 4 the average load from the measured field data were used.

The annual average daily hot water load at each site was between 10,000 and 18,000 Btu/d (17 to $31 \mathrm{gpd}$ at $70^{\circ} \mathrm{F}$ temperature rise). These daily loads were on the lower end of the expected range for a representative range of homes in Minnesota or the United States. A previous water heating field study in Minnesota measured the loads in 10 homes, selected to meet the range of occupants per home, and found an average hot water load of 21,000 Btu/d (or $35 \mathrm{gpd}$ ). The hot water usage rates for this study were on the lower end of the range due to the sizing criteria of the water heaters. All four test sites had two or three people and two showers. Several of the retrofit hybrid water heaters (WH 1 and WH 4) are designed with smaller capacities than traditional tankless water heaters or storage water heaters and the test homes were selected to meet the sizing criteria of these smaller units. The impact this had on the savings potential (see Section 4.2.1) and on delivered quality and meeting the load was analyzed (Section 4.3). 
Table 6. Water Heater Natural Gas Input versus Output Relationship Characteristics

\begin{tabular}{l|l|r|r|r}
\hline Site & WH & Slope & $\begin{array}{r}\text { Intercept } \\
\text { (Btu/d) }\end{array}$ & $\mathbf{R}^{\mathbf{2}}$ \\
\hline 1 & 1 & 1.02 & 5,529 & 0.965 \\
\hline 2 & 2 & 1.28 & 5,090 & 0.976 \\
\hline 3 & 3 & 1.02 & 2,684 & 0.992 \\
\hline 4 & 4 & 1.05 & 5,310 & 0.952 \\
\hline Baseline* $^{*}$ & Natural Draft & 1.46 & 13,145 & NA \\
& Storage & & & \\
\hline
\end{tabular}

*The baseline model is an average of eight natural draft water heaters previously monitored (Bohac et al. 2010).

The natural gas input to each water heater and the hot water energy load from each water heater was measured and summed on a daily basis. The resulting linear relationship for each water heater was used to characterize the water heater's performance (Figure 11). Figure 11 plots the daily measured energy input and hot water output (points) and the linear regressions or models (lines) fitting the measured data. The input-output relation had very strong $\mathrm{R}^{2}$ values $(0.95$ to 0.99 ) for all water heaters for natural gas input. Table 6 summarizes the input-load regression parameters for the baseline water heater and for the four hybrid water heaters included in this project. Previous results for eight identical 0.60 EF, natural draft, 40-gal. storage water heaters were used for the baseline water heater models (Schoenbauer et al. 2011). The linear relationship characterizes the performance of the water heaters. The slope of the line represented the amount of energy input to energy output at steady state, or the inverse of the thermal efficiency. The intercept was a metric for energy use that did not contribute to hot water output from the water heater. The intercept value included impacts from standby loses during inactivity, but also the ramp up and cool down of the unit, which was significant for larger tankless style burners. 


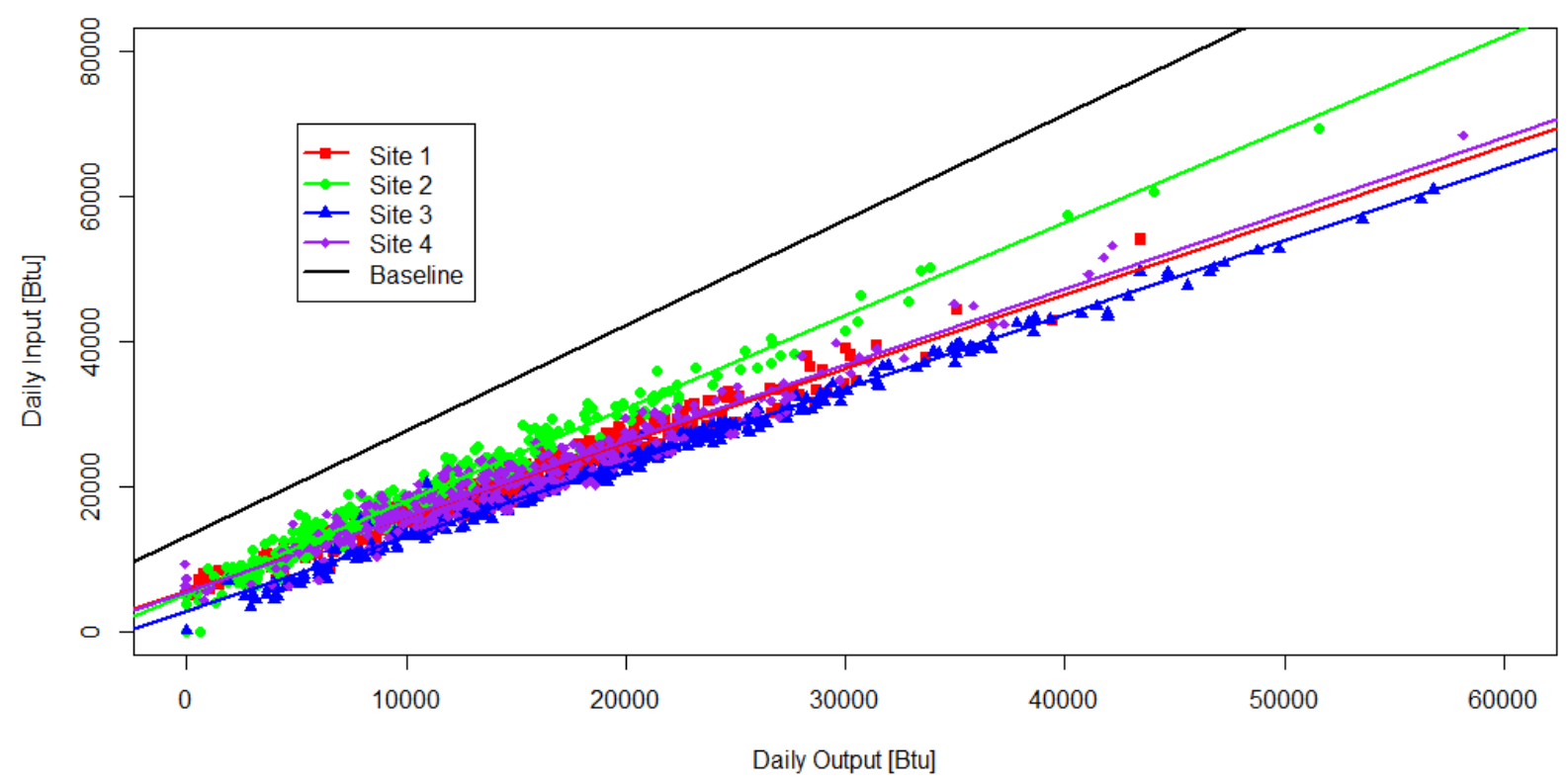

Figure 11. Linear relationship between natural gas input and hot water output for each of the water heaters tested and a baseline technology

The water heater input-output regression model and annual energy output from each site (Table 5) was used to determine the annual energy consumption for each water heater. Table 7 summarizes the energy use calculation results from Equation 3. The annual efficiency was the computed efficiency under the installed conditions in the field. The hot water usage measured at these test sites was significantly less than the hot water volume of the EF and thermal efficiency test methodologies. This difference in the installed hot water usage as well as differences in water temperatures and ambient air temperatures resulted in lower efficiencies that the rated values under the required test conditions in a laboratory. The smaller loads increased the impact of standby loses, which were greater for WH 2 and WH 4, the two that had larger storage volumes. The cost-effectiveness section (Section 4.2) discusses the savings and cost calculations. 
Table 7. Energy Use Calculation Summary

\begin{tabular}{|c|c|c|c|c|c|}
\hline \multirow[b]{2}{*}{ Site } & \multirow[b]{2}{*}{ WH } & \multicolumn{4}{|c|}{ Energy Use Calculations } \\
\hline & & $\begin{array}{l}\text { Annual } \\
\text { Mains } \\
\text { Temperature } \\
\text { (F) }\end{array}$ & $\begin{array}{l}\text { Annual } \\
\text { Average } \\
\text { Daily } \\
\text { Output } \\
\text { (Btu/d) }\end{array}$ & $\begin{array}{l}\text { Annual } \\
\text { Average } \\
\text { Daily Energy } \\
\text { Use (Btu/d) }\end{array}$ & $\begin{array}{l}\text { Annual } \\
\text { Average } \\
\text { Efficiency }\end{array}$ \\
\hline 1 & 1 & 49 & 13,544 & 19,390 & $70 \%$ \\
\hline 2 & 2 & 52 & 9,870 & 17,752 & $56 \%$ \\
\hline 3 & 3 & 54 & 18,203 & 21,304 & $85 \%$ \\
\hline 4 & 4 & 51 & 15,177 & 21,297 & $71 \%$ \\
\hline
\end{tabular}

Larger daily hot water loads result in higher water heater efficiencies. Figure 12 shows the efficiency curves for each of the hybrid water heaters. The annual efficiencies calculated for each water heater as installed in each home would have been significantly higher if the water heating loads had been higher. For example, the load for Site 2 was only 10,000 Btu/d, which resulted in a 54\% annual efficiency (this low efficiency still provided a 36\% energy savings over the baseline water heater). For a $40,000 \mathrm{Btu} / \mathrm{d}$ load the efficiency would have increased to $72 \%$.

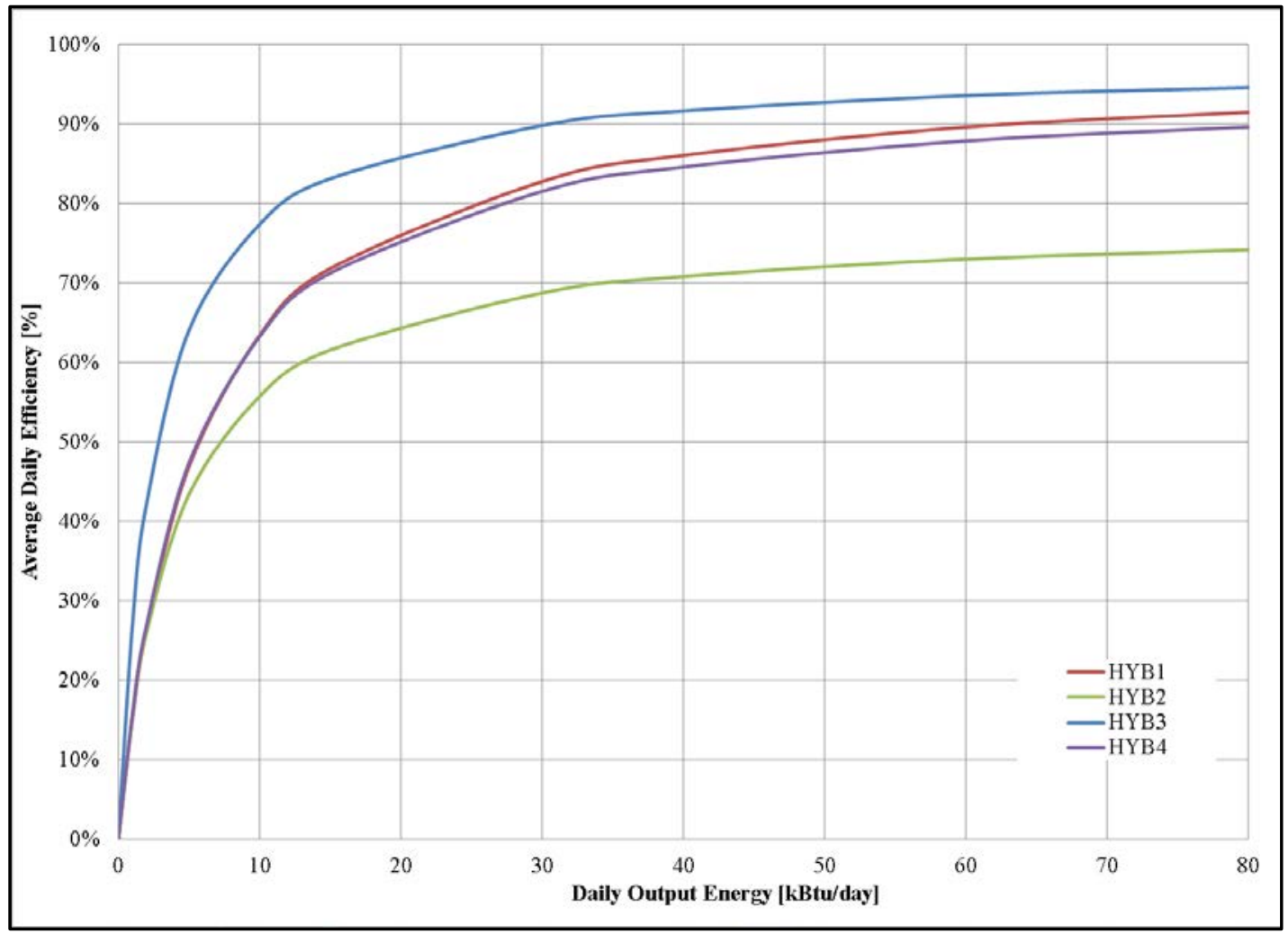

Figure 12. Regression of daily efficiency for each of the hybrid water heaters 


\subsubsection{Electrical Consumption}

Baseline, or natural-draft storage water heaters, typically have no electrical connection. The hybrid water heaters in this study required an electrical connection in addition to the natural gas consumption previously discussed. Electricity was used to power an exhaust fan, gas burner, and control board. The annual electricity use consisted of a standby portion and an active portion. The standby use was independent of DHW load and consisted of a small amount for electricity to keep the control board active and to fire the burner to compensate for storage standby heat loss. The active part of the electric consumption came from the burner ignition cycle and hot water draw events. The active electrical consumption consisted of use by the control and sensing components, the burner ignition and operation, and the exhaust fan. Figure 13 and Figure 14 show the electric power (orange) for a typical hot water draw and burner event, respectively. The active consumption varied with DHW load. 

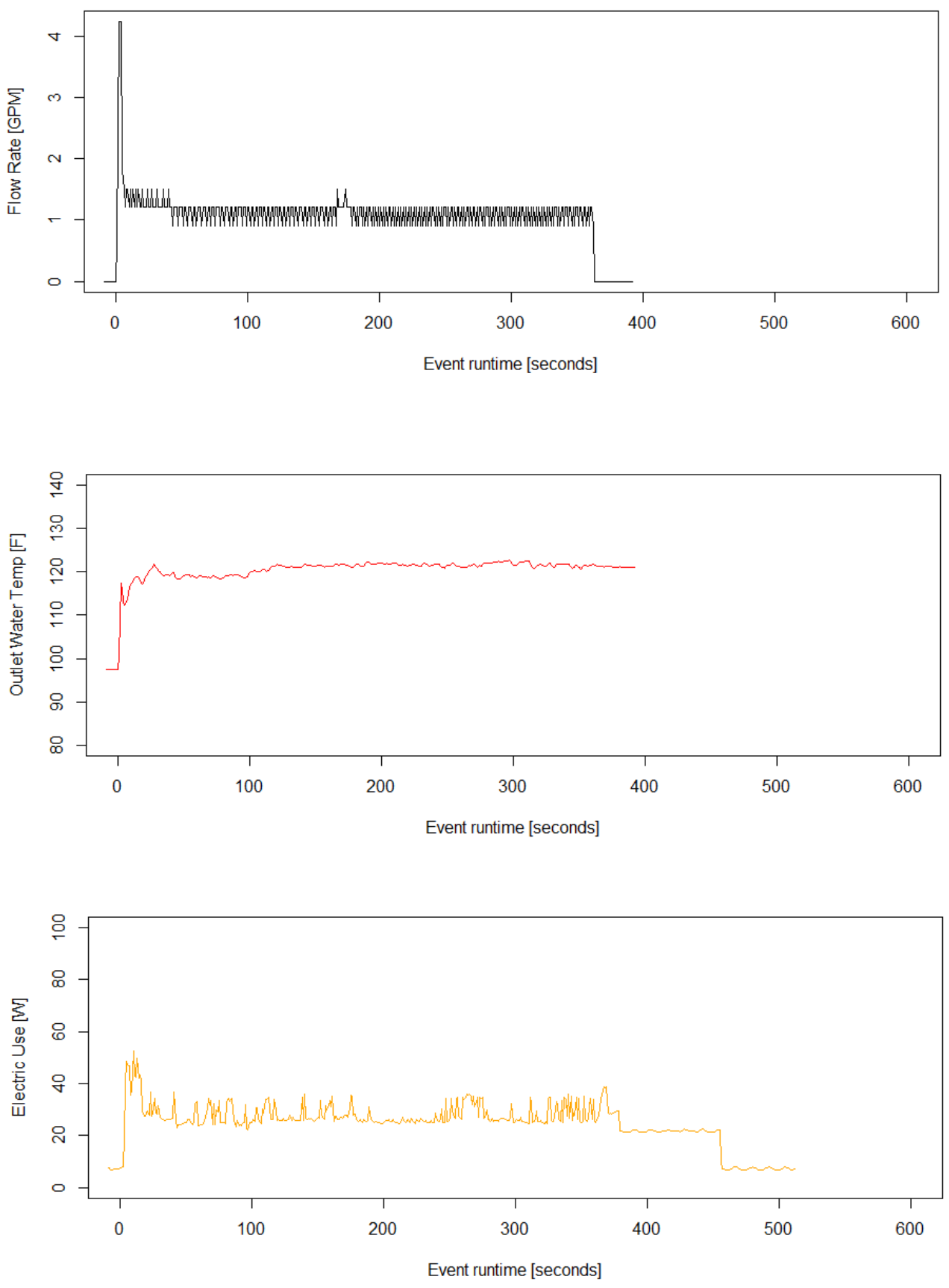

Figure 13. Flow rate, outlet temperature, and electric power during a typical hot water draw 

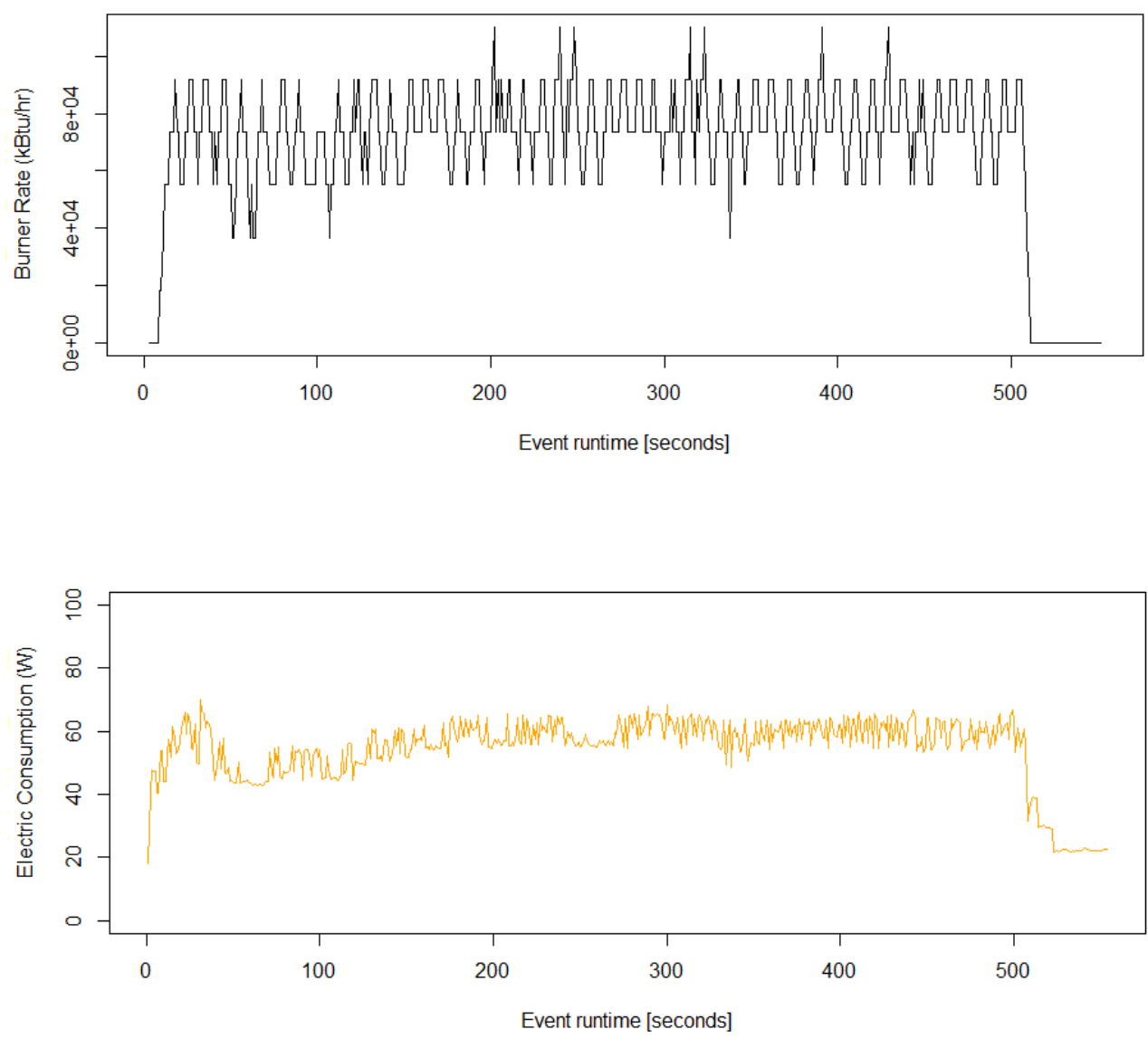

Figure 14. Burner fire rate and electric power during a typical burner fire

Because the active electrical consumption varied with DHW output and the standby electrical consumption was static, a well-defined linear regression could be computed between the daily average water heater output and the electric use. Figure 15 and Table 8 show the electric input to DHW output model parameters at each site. The electrical consumption accounted for less than $5 \%$ of the total site water heating energy use at each site. WH 2 - the hybrid noncondensing tankless and 40-gal. storage water heater-had electrical consumption that increased with daily hot water usage. The water heaters with smaller storage capacities (WH 1, 3, and 4) had electrical consumption that had a less significant correlation with hot water output and therefore a flatter slope in Figure 15. 


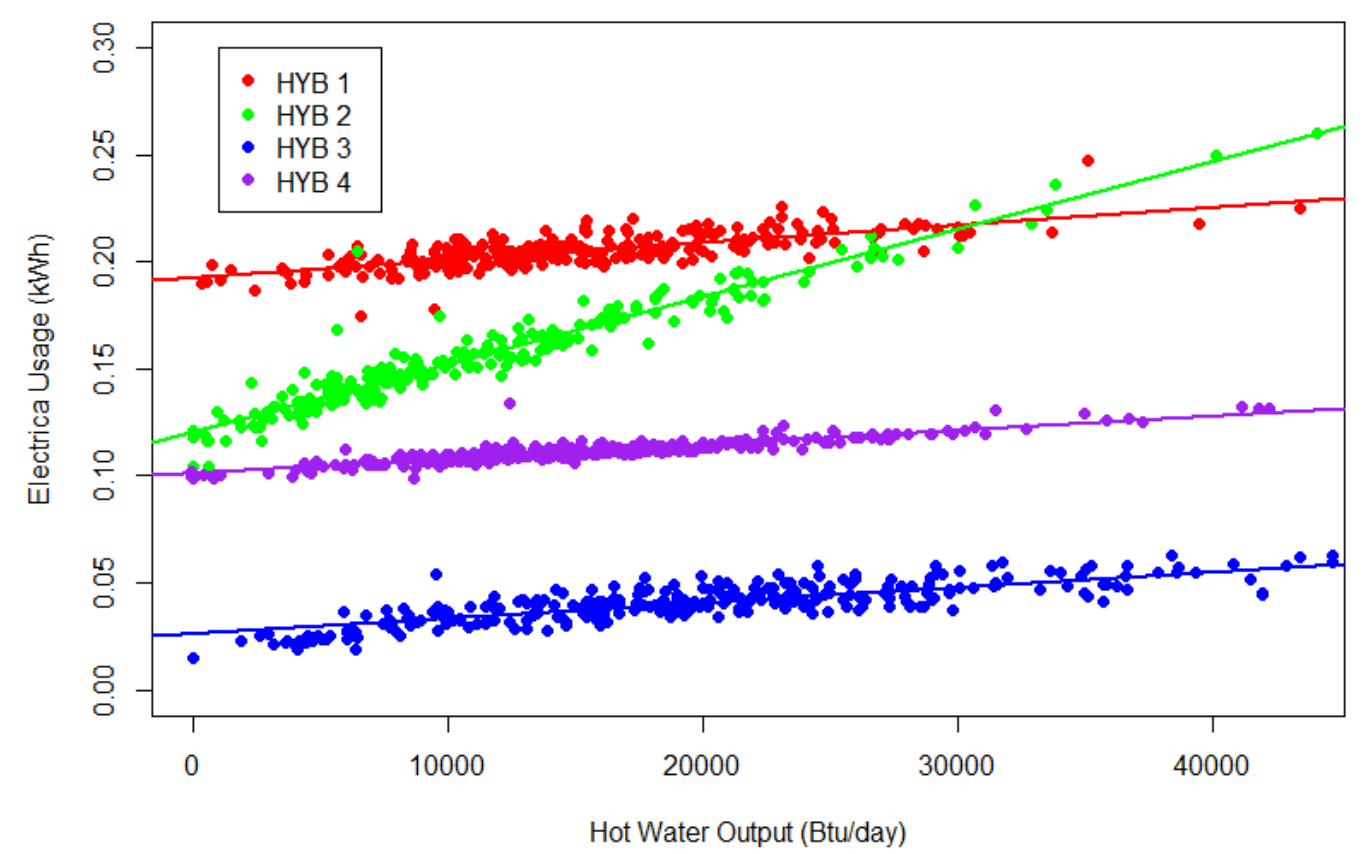

Figure 15. Daily electric consumption for each water heater

Table 8. Water Heater Electric Consumption Linear Model Parameters

\begin{tabular}{l|l|r|r|r|r|r}
\hline Site & WH & $\begin{array}{r}\text { Slope } \\
\text { (kWh/Btu) }\end{array}$ & $\begin{array}{r}\text { Intercept } \\
\text { (Btu/d) }\end{array}$ & $\mathbf{R}^{\mathbf{2}}$ & $\begin{array}{r}\text { Annual } \\
\text { Electric Use } \\
\mathbf{( k W h )}\end{array}$ & $\begin{array}{r}\text { Percentage } \\
\text { of Total WH } \\
\text { Site Energy } \\
\text { Use }\end{array}$ \\
\hline 1 & 1 & $8.3 \mathrm{E}-07$ & 0.19 & 0.54 & 74 & $3.4 \%$ \\
\hline 2 & 2 & $3.2 \mathrm{E}-06$ & 0.12 & 0.93 & 55 & $2.8 \%$ \\
\hline 3 & 3 & $7.2 \mathrm{E}-07$ & 0.03 & 0.69 & 14 & $0.6 \%$ \\
\hline 4 & 4 & $6.7 \mathrm{E}-07$ & 0.10 & 0.86 & 41 & $1.8 \%$ \\
\hline Baseline & ND StWH & 0 & 0.00 & NA & 0 & $0.0 \%$ \\
\hline
\end{tabular}

\subsection{Cost-Effectiveness}

Cost-effectiveness results for a range of water heater loads, incremental costs of water heater installation follow.

\subsubsection{Savings for a Range of Loads}

These usage categories cover the range of water heating use expected in typical homes across the country. Table 9 shows the natural gas consumption that would be required to meet each of a very small, low, medium, and high load category for the tested water heaters and a baseline natural draft storage water heater. Table 10 shows the savings for each tested water heater over the baseline. The annual savings uses a gas cost of $\$ 0.80 /$ therm and includes a small reduction 
due to the electrical consumption of the tested water heaters. The very small category was created for water heaters supplying individual fixtures at $10 \mathrm{gpd}$. While the savings for this category were very small ( $\$ 21$ to $\$ 27$ per year), this type of installation would be atypical for these water heaters. Annual savings of $\$ 30$ to $\$ 90$ were found for the whole house installation range (low, medium, and high usage). This represented a $20 \%$ to $40 \%$ reduction in the water heating energy costs.

Table 9. Annual Gas Consumption for a Range of Household Hot Water Loads

\begin{tabular}{l|r|r|r|r|r|r|r}
\hline & & & \multicolumn{4}{|c}{ Annual Natural Gas Use (therms) } \\
\cline { 5 - 9 } Usage & $\begin{array}{r}\text { Hot Water } \\
\text { Use (gpd) }\end{array}$ & $\begin{array}{r}\text { Hot Water } \\
\text { Output } \\
\text { (Btu/d) }\end{array}$ & WH 1 & WH 2 & WH 3 & WH 4 & Base \\
\hline Very Small & 10 & 5,561 & 40 & 45 & 31 & 39 & 78 \\
\hline Low-Usage & 38 & 21,132 & 100 & 117 & 89 & 102 & 160 \\
\hline Medium & 55 & 30,586 & 136 & 161 & 124 & 140 & 211 \\
\hline High-Usage & 84 & 46,712 & 198 & 235 & 184 & 204 & 296 \\
\hline
\end{tabular}

Table 10. Annual Cost Savings for a Range of Household Hot Water Loads

\begin{tabular}{|c|c|c|c|c|c|c|}
\hline \multirow[b]{2}{*}{ Usage } & \multirow[b]{2}{*}{$\begin{array}{l}\text { Hot Water } \\
\text { Use (gpd) }\end{array}$} & \multirow[b]{2}{*}{$\begin{array}{r}\text { Hot Water } \\
\text { Output } \\
\text { (Btu/d) }\end{array}$} & \multicolumn{4}{|c|}{ Annual Natural Gas Savings (\$) } \\
\hline & & & WH 1 & WH 2 & WH 3 & WH 4 \\
\hline Very Small & 10 & 5,561 & $\$ 23$ & $\$ 21$ & $\$ 36$ & $\$ 27$ \\
\hline Low-Usage & 38 & 21,132 & $\$ 41$ & $\$ 28$ & $\$ 56$ & $\$ 43$ \\
\hline Medium & 55 & 30,586 & $\$ 52$ & $\$ 32$ & $\$ 68$ & $\$ 52$ \\
\hline High-Usage & 84 & 46,712 & $\$ 70$ & $\$ 39$ & $\$ 88$ & $\$ 69$ \\
\hline
\end{tabular}

\subsubsection{Savings, Incremental Costs, and Cost-Effectiveness}

Table 11 provides the cost data for baseline and retrofit hybrid water heaters. The cost data were collected from contractor estimates and discussion based on their experience with this project and with natural gas water heater installation. The installation costs from this project were tracked, but were not used directly as it was difficult to break out added costs from project instrumentation. Baseline water heater, condensing storage water heater (CStWH), and condensing tankless water heater $(\mathrm{CTWH})$ costs have been provided for comparison and represent an average cost based on mechanical contractor standard costs. The costs assumed a baseline cost of $\$ 950$ to $\$ 1,300$ for a natural draft water heater replacement. Advanced highefficiency water heater installs traditionally require several steps that baseline replacements would not, such as:

- Gas line and meter assessment and replacement with increased capacity

- Vent line replacement and possible relocation 
- Water heater relocation to accommodate venting and gas line modifications

- Minor plumbing modifications to fit pipe connections to new water heater size and location.

Each of these additional steps adds to the incremental cost of the water heater installation. Table 12 lists the impact each of these steps has on the retrofit hybrid water heaters. WH 1, WH 3, and WH 4 all had similar installation requirements. Each was designed to use the existing gas line and meter with no modifications. The vent and intake air ducting was designed to utilize materials that were inexpensive and easy to use. Additionally, the vent systems were designed to minimize clearance requirements from the exhaust termination, reducing the installation difficulty and potential need to relocate the water heater. All three of these water heaters were smaller than the water heater they replaced and the change in physical size required minor plumbing modifications for each job. However, because the new water heaters were smaller, there was flexibility in the plumbing modifications. WH 4 had a slightly different approach; it used a less efficient burner with $80 \%$ thermal efficiency compared to $90+\%$ for other hybrid systems. This approach allowed WH 2 to utilize the existing vent system and, as it was similar in physical size to the existing water heater, it reduced the necessary plumbing modifications. The only incremental cost expected for a baseline water heater being replaced by WH 4 was the incremental cost of the water heater itself.

Table 11. Equipment and Install Costs for Retrofit Hybrid Water Heaters

\begin{tabular}{l|l|l|l|l|l|l|l}
\hline & Baseline & WH 1 & WH 2 & WH 3 & WH 4 & CStWH & CTWH \\
\hline Water Heater Cost & $\$ 450$ & $\$ 1,200$ & $\$ 1,350$ & $\$ 1,450$ & $\$ 1,000^{*}$ & $\$ 2,500$ & $\$ 1,600$ \\
Install Cost & $\begin{array}{l}\$ 400 \text { to } \\
\$ 850\end{array}$ & $\begin{array}{l}\$ 800 \text { to } \\
\$ 1,250\end{array}$ & $\begin{array}{l}\$ 400 \text { to } \\
\$ 850\end{array}$ & $\begin{array}{l}\$ 800 \text { to } \\
\$ 1,250\end{array}$ & $\begin{array}{l}\$ 100 \text { to } \\
\$ 1,250\end{array}$ & $\begin{array}{l}\$ 1,000 \text { to } \\
\$ 1,250\end{array}$ & $\$ 1,500$ to \\
&
\end{tabular}

* Anticipated cost as product was not commercially available at the time of reporting

Table 12. Incremental Tasks for Hybrid Water Heater Installation

\begin{tabular}{l|l|l|l|l}
\hline & WH 1 & WH 2 & WH 3 & WH 4 \\
\hline Gas line modification & No & No & No & No \\
Vent line modification & Yes & No & Yes & Yes \\
WH relocation & Minor & No & Minor & Minor \\
Plumbing modification & Minor & No & Minor & Minor \\
\hline
\end{tabular}

Despite the reduced incremental costs and the significant (20\% to $40 \%)$ reduction in energy use, the paybacks for all four water heaters were still over 10 years (Table 13). However, they did show improved paybacks over condensing storage and condensing tankless water heaters. The energy savings from the retrofit hybrids were similar when compared to other condensing water heaters and the installation costs were considerably cheaper. The low fuel costs and relatively low baseline water heater energy costs make it difficult to achieve short paybacks. The incremental cost of a condensing water heater would need to be between $\$ 200$ and $\$ 400$ dollars to achieve a 6-year simple payback versus a natural draft water heater. In all cases this is greater 
than the incremental cost of the water heater itself. In order for condensing water heaters to achieve shorter paybacks over natural draft water heaters the water heater costs must be reduced.

Table 13. Annual Cost Savings and Simple Paybacks

\begin{tabular}{l|l|l|l|l|l|l}
\hline \multirow{2}{*}{ Site \& WH } & \multicolumn{3}{|l|}{ Annual Savings (\$/yr) } & \multicolumn{3}{l}{ Simple Payback (yrs) } \\
\cline { 2 - 7 } & Low & Medium & High & Low & Medium & High \\
\hline 1 & $\$ 41$ & $\$ 52$ & $\$ 70$ & 28 & 22 & 16 \\
2 & $\$ 28$ & $\$ 32$ & $\$ 39$ & 32 & 28 & 23 \\
3 & $\$ 56$ & $\$ 68$ & $\$ 88$ & 25 & 21 & 16 \\
4 & $\$ 43$ & $\$ 52$ & $\$ 69$ & 22 & 18 & 14 \\
\hline
\end{tabular}

Note: These energy costs assume $\$ 0.80 /$ therm and $\$ 0.10 / \mathrm{kWh}$

\subsection{Delivered Quality}

Results of the delivered water quality analysis include water heater start-up performance, hot water capacity, and never-hot events.

\subsubsection{Start-Up Performance}

Figure 16 shows the 1-second variation in outlet water temperature within 6 in. of the water heater for all monitored draws for each of the hybrid water heaters tested. Each draw starts at time $=0$ and the trace continues for 120 seconds or until the end of the draw. The outlet water temperature traces show the water heaters' ability to deliver hot water at the desired temperature. These plots visually demonstrate water temperature consistency and delay time. 
Site 1

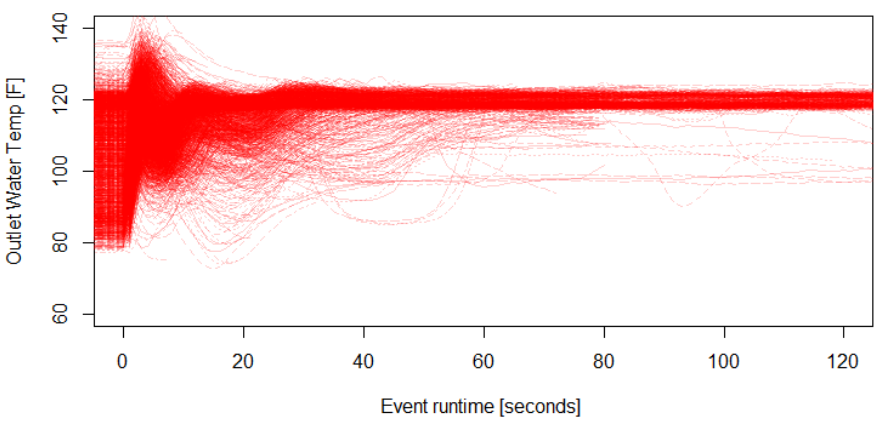

Site 2

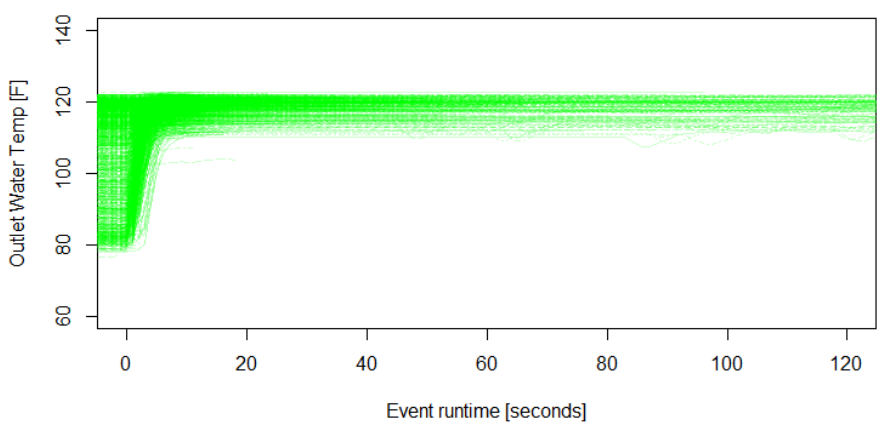

Site 3

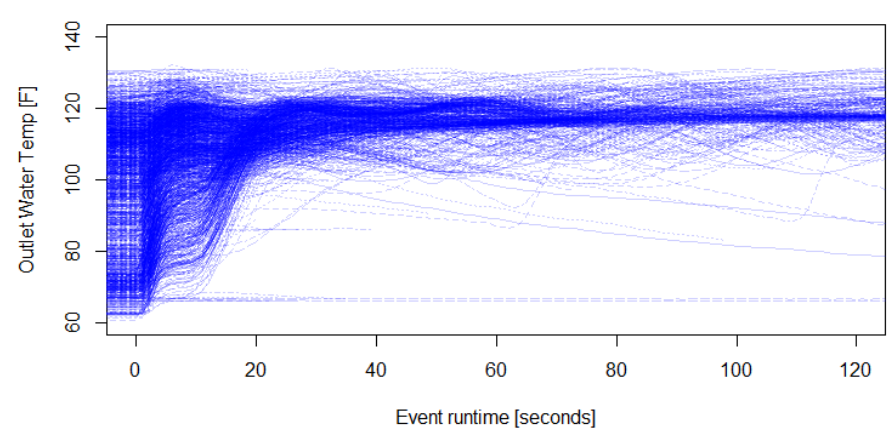

Site 4

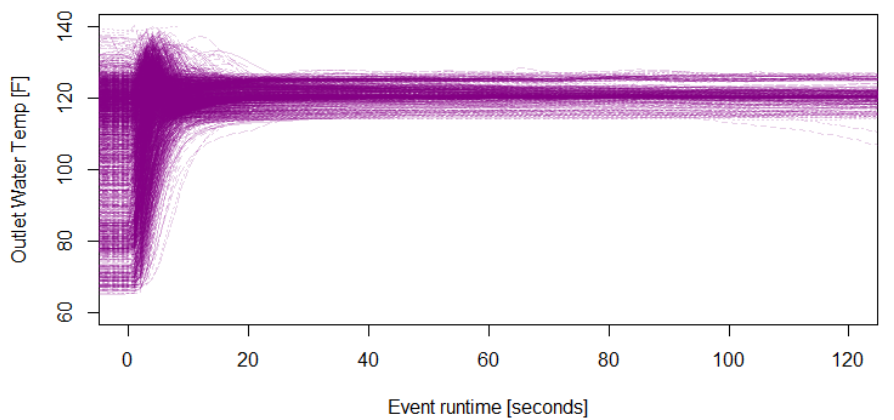

Figure 16. Outlet temperature time series plots for hot water events 
The hybrid water heater at Site 1 had 2 gal. of storage capacity and was controlled by a temperature sensor in the internal tank. When the tank temperature dropped below a manufacturer specified amount (approximately $20^{\circ} \mathrm{F}$ below the set point) the burner fired to heat the tank. The relatively large dead-band and small tank volume caused significant temperature fluctuations at the start of some hot water draws. Within the first 10 seconds of hot water events there were fluctuations as great as $20^{\circ} \mathrm{F}$ above the set point. The control strategy implemented by this water heater design provided a shorter hot water delay time than a traditional tankless water heater with no storage capacity, although there was still some delay compared to the instant delivery of a storage water heater (Figure 17). For the purpose of this analysis water temperatures within $5 \%$ of the set point temperature are considered at temperature. Figure 18 shows the fraction of hot water events that were within $5 \%$ of the set point temperature for each 1 -second interval over the first 2 minutes of the draw. For WH 1, 36\% of the events were not at set point at 10 seconds into a hot water event. By 30 seconds $14 \%$ of events were still not at the set point, but at 60 seconds less than $5 \%$ of the hot water events were not at the set point temperature.
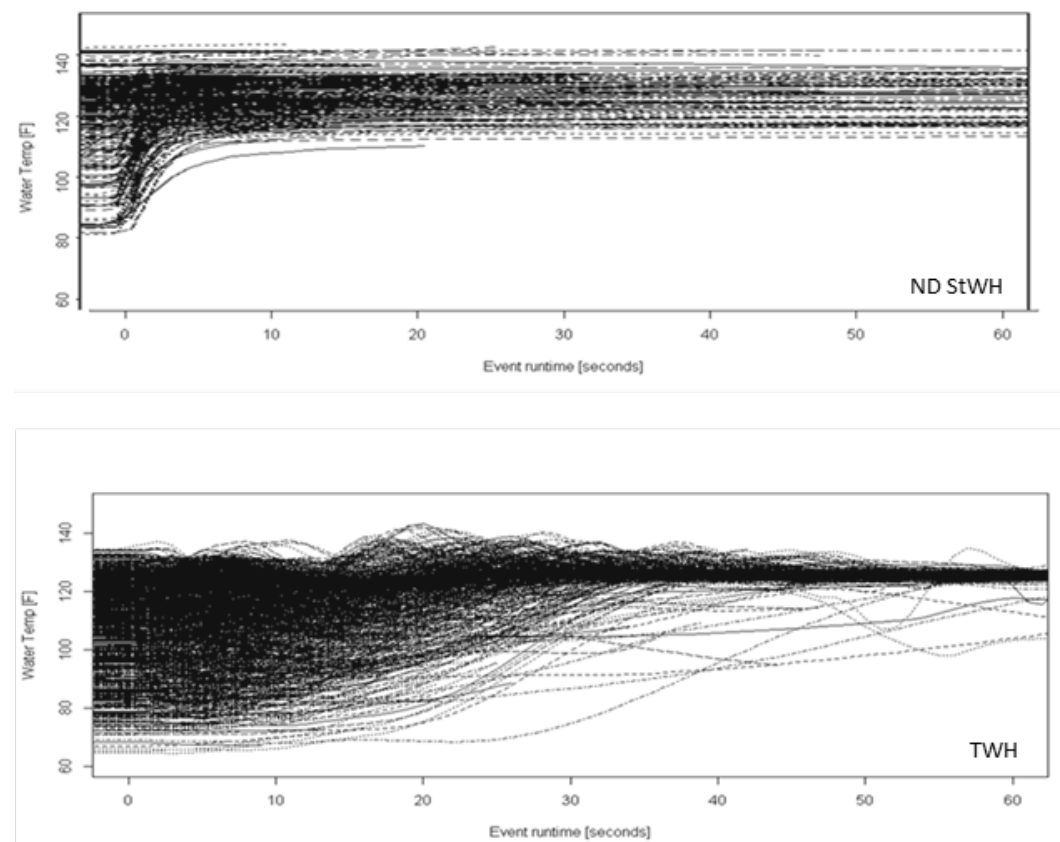

Figure 17. Outlet temperature time series plots for hot water events for a natural draft storage WH and a tankless WH 


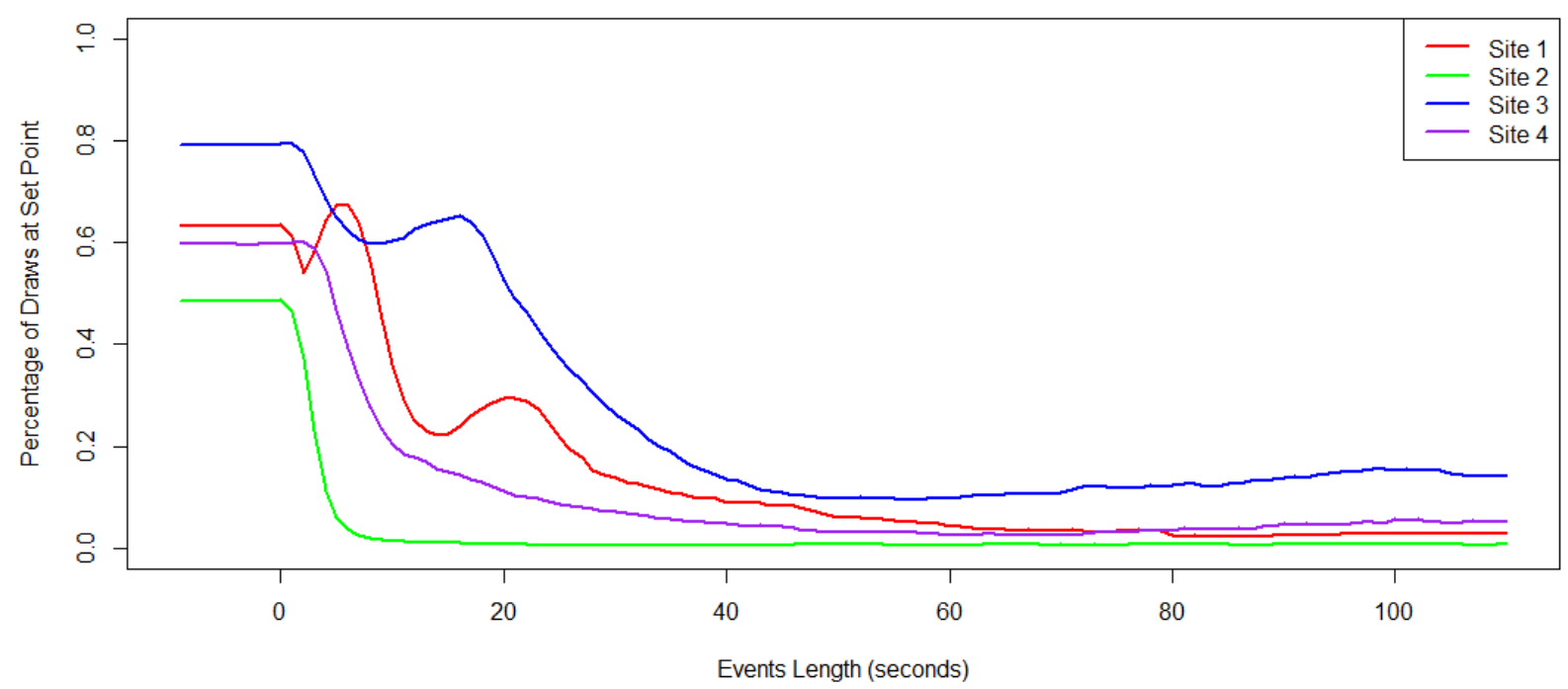

Figure 18. Fraction of draws with greater than $5 \%$ variance from set point, by time from the start of draw

The hybrid water heater at Site 2 had 40 gal. of storage capacity. The storage volume temperature was controlled using a temperature sensor in the storage tank, like most other storage water heaters. The large storage volume increased the outlet temperature stability compared to the smaller volume of the water heater at Site 1 . For this water heater, only $2 \%$ of the draws were not at set point by 10 seconds after the start of a hot water event, representing instantaneous hot water delivery.

The hybrid water heater at Site 3 had only $1 / 2$ gal. of storage capacity. It appears that this water heater primarily relies on faster burner control to achieve the desired outlet temperature and uses the small buffer tank to reduce the control delay. Figure 18 shows that of the four hybrid water heaters, this design had the longest hot water delay time. At 10 seconds after the start of a hot water event over $60 \%$ of the draws were not at set point, at 30 seconds $26 \%$ were still not at the set temperature, and even at 2 minutes $15 \%$ of draws were not at set point. The steady state control of delivered water temperature was more difficult with the design approach used with WH 3. Figure 16 shows that for the water heaters at Site 1, Site 2, and Site 4, the majority of hot water events were within 5\% of the set point temperature at 60 seconds and there was little temperature change between 60 seconds and 120 seconds. At Site 3 there was still significant temperature variance between the first and second minute of many of the hot water events. Over time, some of the variance at the outlet of the water heaters will be buffered and smoothed by the volume of water in the pipe. It should also be noted that even though WH 3 had the least consistent delivery temperature in the project, there were no occupant complaints for Site 3.

The hybrid water heater at Site 4 had 20 gal. of storage capacity and a fixed burner input of $100,000 \mathrm{Btu} / \mathrm{h}$. While this storage water heater had some of the small overheating issues of WH 1 within the first 5 to 10 seconds of events, overall it behaved similarly to a baseline storage 
water heater. After the start of a hot water event, $20 \%$ of the draws were not at set point at 10 seconds, but by 30 seconds only $7 \%$ of the hot water events were not at set point.

\subsubsection{Capacity or Running Out of Hot Water}

The maximum capacity of water heaters is specified by the first hour rating or the maximum flow rate. These ratings were used to determine the maximum gallons of hot water a water heater can produce in one hour. The hybrid retrofit water heaters all have capacities of 160 gal. per hour (gph) or greater (WH 1 is $168 \mathrm{gph}, \mathrm{WH} 2$ is $228 \mathrm{gph}, \mathrm{WH} 3$ is $180 \mathrm{gph}$, and WH 4 is $160 \mathrm{gph}$ ). The measured hot water use data were used to determine the hour of each day with the largest use of hot water at each site (Figure 19).

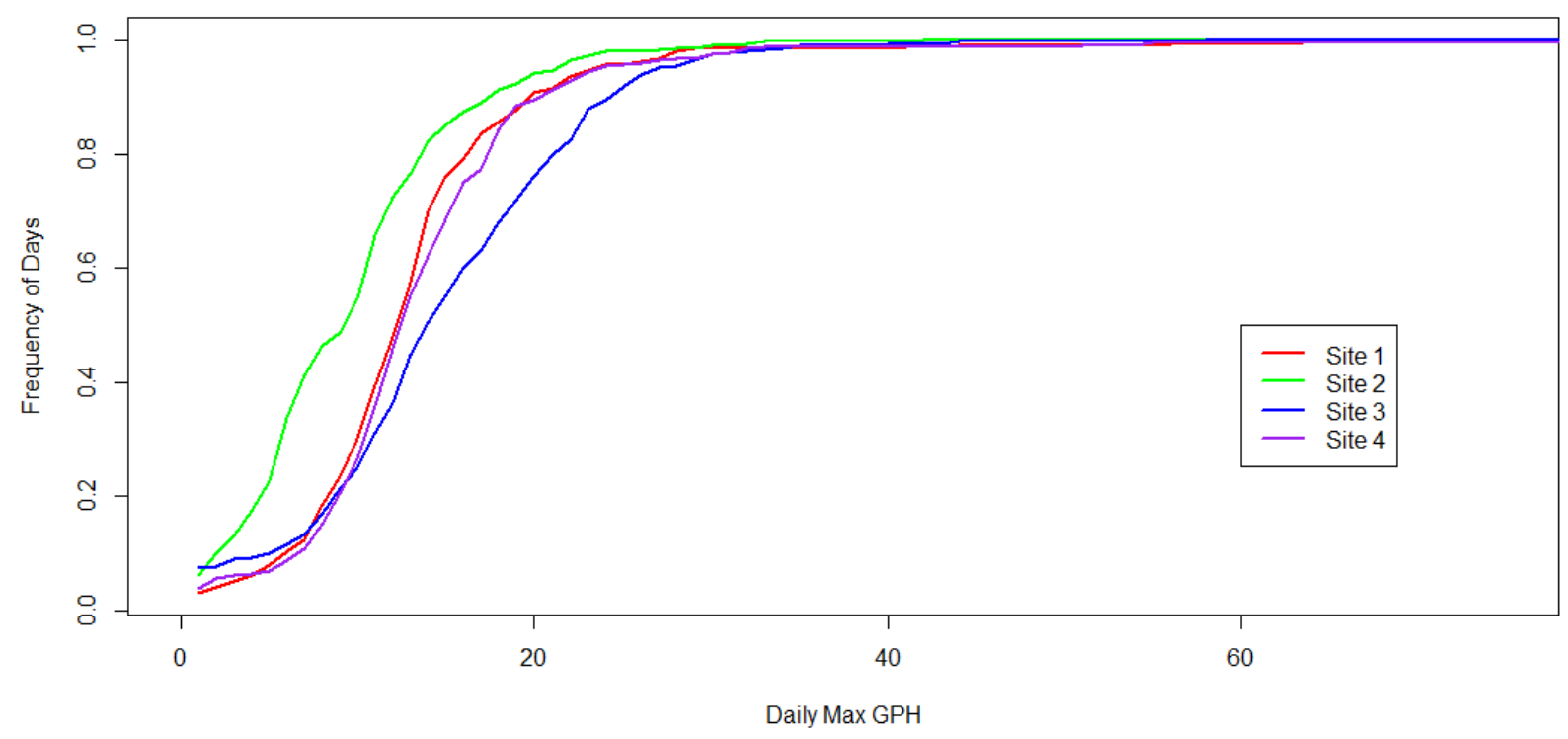

Figure 19. Daily maximum hourly hot water use at each site

The largest volume of hot water used in any hour of monitored data was 152 gal. at Site 1 . There were no hours of operation that exceeded the hourly capacity of any of the water heaters. Less than $1 \%$ of days had hours that exceed 40 gal. of hot water use. These data show that the water heaters were adequately sized and met the capacity of the homes based on their ratings. Water heaters were sized based on peak load, which would occur with all showers at maximum flow. Peak flow rates and maximum hourly volumes indicated that simultaneous showers were rare. Therefore, water heaters were properly sized for peak loads, but peak hot water use was rare enough that it would be feasible to redefine peak as something less than all showers at maximum flow.

\subsubsection{Never-Hot Events}

For all four water heaters tested, less than five draws were longer than 120 seconds and did not reach temperature in the full monitoring period. The only draws that never delivered hot water were very short in length. These were draws that had outlet water temperature profiles that would have eventually resulted in hot water, but the fixture was closed prior to hot water being 
delivered from the water heater. Figure 20 shows that about $50 \%$ of all events were shorter than 20 seconds and many of those draws were still coming up to temperature when the event ended. However, in most plumbing configurations 20 seconds would not have been enough time for the hot water to reach the fixture through the distribution system. Because of this, it can be assumed that the users did not require hot water, even though a hot water fixture was used.

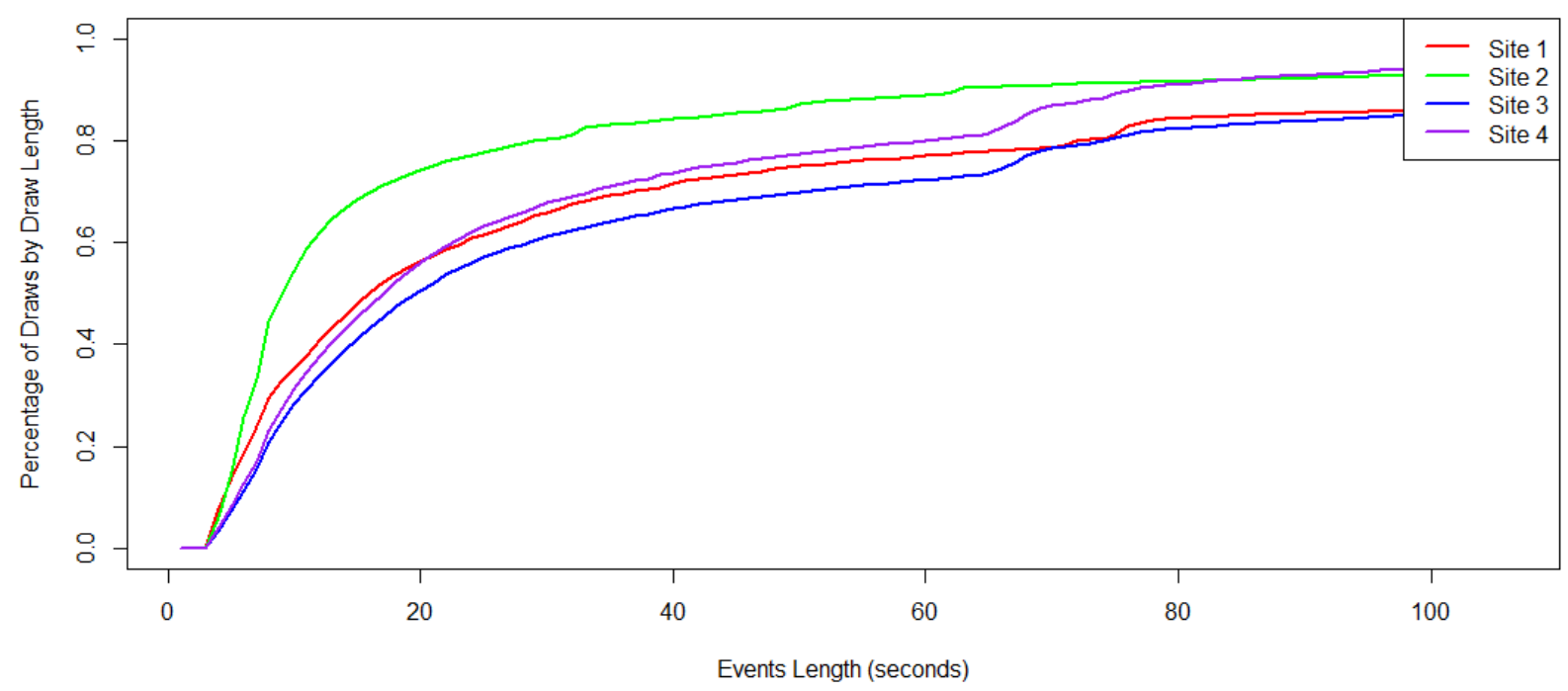

Figure 20. Fraction of draws by total length (percentage of draws shorter than $x$-axis value)

\subsection{Performance in Other Climate Zones}

The inlet or main water temperature is influenced by many factors including ground temperature, air temperature, source water type, and distribution system. Because these factors vary significantly by climate, the annual average main water temperature also varies by climate. Table 14 shows the annual average main water temperatures for representative cities in each of the Building America Climate Zones. 
Table 14. Main Inlet Water Temperature Conditions for Each Site $\left({ }^{\circ} \mathrm{F}\right)$.

\begin{tabular}{|c|c|c|c|c|c|}
\hline \multirow[b]{2}{*}{$\begin{array}{l}\text { Climate } \\
\text { Zone }\end{array}$} & \multirow[b]{2}{*}{ Representative City } & \multirow{2}{*}{$\begin{array}{l}\text { TMY3 } \\
\text { Average } \\
\text { Outdoor } \\
\text { Temp }\end{array}$} & \multicolumn{3}{|c|}{ Main Water Temperature Conditions } \\
\hline & & & $\begin{array}{l}\text { Annual } \\
\text { Average }\end{array}$ & $\begin{array}{l}\text { Daily } \\
\text { Minimum }\end{array}$ & $\begin{array}{l}\text { Daily } \\
\text { Maximum }\end{array}$ \\
\hline $1 \mathrm{~A}$ & Miami, FL & 76 & 82 & 76 & 88 \\
\hline $2 \mathrm{~A}$ & Houston, TX & 69 & 75 & 64 & 85 \\
\hline $2 \mathrm{~B}$ & Phoenix, AZ & 75 & 81 & 66 & 96 \\
\hline $3 A$ & Atlanta, GA & 62 & 68 & 56 & 80 \\
\hline 3B-CA & Los Angeles, CA & 62 & 68 & 65 & 72 \\
\hline 3B-other & Las Vegas, NV & 68 & 74 & 59 & 88 \\
\hline $3 C$ & San Francisco, CA & 57 & 63 & 59 & 66 \\
\hline $4 \mathrm{~A}$ & Baltimore, MD & 56 & 62 & 50 & 74 \\
\hline 4B & Albuquerque, NM & 57 & 63 & 52 & 74 \\
\hline $4 \mathrm{C}$ & Seattle, WA & 52 & 58 & 52 & 64 \\
\hline $5 \mathrm{~A}$ & Chicago, IL & 50 & 56 & 44 & 68 \\
\hline $5 \mathrm{~B}$ & Denver, CO & 52 & 58 & 48 & 67 \\
\hline $6 \mathrm{~A}$ & Minneapolis, MN & 46 & 52 & 39 & 65 \\
\hline $6 \mathrm{~B}$ & Helena, MT & 45 & 51 & 42 & 60 \\
\hline $7^{*}$ & Duluth, MN & 39 & 45 & 36 & 55 \\
\hline $8^{*}$ & Fairbanks, AK & 29 & 35 & 27 & 44 \\
\hline
\end{tabular}

*Burch and Christensen 2007 notes that the mains model temperatures do not correlate well with field data in locations with near continuous snow cover.

The main temperature profiles were computed using Typical Meteorological Year 3 (TMY3) ${ }^{1}$ data for the representative cities and a simulation model. Average main temperatures rose as high as $82^{\circ} \mathrm{F}$ in Miami, a $30^{\circ} \mathrm{F}$ increase compared to the average temperature for Minneapolis. This increased inlet water temperature condition will reduce the amount of energy required to meet the same hot water demand. In Miami, water needs to be heated to only $43^{\circ} \mathrm{F}$ to meet a $125^{\circ} \mathrm{F}$ set point, compared to a required $73^{\circ} \mathrm{F}$ temperature rise in Minneapolis. This reduced temperature rise requires less energy to meet the load. For example, a medium use home with a water use of 55 gpd will require $41 \%$ less energy for hot water heating in Miami than Minneapolis. This estimate assumed that a change in cold water inlet temperature would not change the volume consumed. In reality, blended draws such as showers require less hot water when the cold water used to blend is warmer. Therefore, homes with warmer main water temperatures require have lower hot water output than sites with cooler main temperatures. Table 15 shows the impact of the range of main water temperatures on water heater energy consumption. Warmer climates have significantly lower DHW loads and therefore significantly lower energy consumptions and saving potential. This reduction will also impact the economics and paybacks for water heater technologies.

\footnotetext{
${ }^{1}$ Typical Meteorological Year 3: http://rredc.nrel.gov/solar/old_data/nsrdb/1991-2005/tmy3/.
} 
Table 15. Natural Gas Usage for Hybrid Water Heaters Under Medium Load in Various Climates

\begin{tabular}{l|r|r|r|r|r|r|r}
\hline & & & \multicolumn{4}{|c}{ Annual Natural Gas Use (therms) } \\
\cline { 5 - 9 } & $\begin{array}{r}\text { Avg. Main } \\
\text { Water } \\
\text { Lemp (F) }\end{array}$ & $\begin{array}{r}\text { Hot Water } \\
\text { Output } \\
\text { (Btu/d) }\end{array}$ & Baseline & WH 1 & WH 2 & WH 3 & WH 4 \\
\hline Minneapolis & 52 & 33,325 & 225 & 145 & 175 & 134 & 147 \\
\hline Albuquerque & 63 & 28,303 & 199 & 126 & 151 & 116 & 128 \\
\hline Los Angeles & 68 & 26,021 & 186 & 117 & 141 & 107 & 119 \\
\hline Miami & 82 & 19,630 & 152 & 93 & 111 & 83 & 95 \\
\hline
\end{tabular}

\subsection{Comparing Advanced Water Heater Efficiency}

Tankless water heaters and condensing storage water heaters have previously been available to homeowners seeking a high-efficiency gas water heater. These water heaters deliver significant energy savings and increased water heating efficiency. However, they come at a high initial cost and have long paybacks. Hybrid water heaters deliver the same level of efficiency and energy savings with a design to increase delivery quality and reduce the initial cost. Data were compiled from several field studies (Bohac et al. 2010; Schoenbauer 2012; Hoeschele 2012) to compare the installed performance of many different types of high-efficiency gas water heaters to a group of baseline water heaters. The baseline systems were natural draft storage water heaters. Under a daily load of $55 \mathrm{gpd}(31,000 \mathrm{Btu} / \mathrm{d})$ of hot water the baseline natural draft storage water heaters had measured efficiencies at installed operating conditions of 38\% to 65\% (Figure 21).

Condensing storage water heaters had measured efficiencies between $65 \%$ and $75 \%$. The condensing tankless water heaters had the highest measured efficiencies, between $78 \%$ and $92 \%$ at 55 gpd of hot water.

The retrofit hybrid water heaters had measured efficiencies that reflected their design. WH 3 had the highest efficiency of the hybrid heaters measured. With only $1 / 2$ gal. of storage capacity this unit was most similar in design and performance to a condensing tankless water heater. At lower usage volumes the efficiency was reduced due to the increased impact of the heat loss from the storage. Under higher usage, that heat loss of the buffer tank was a smaller portion of the total energy use, and the efficiency of WH 3 matched that of the most efficient condensing tankless water heaters. WH 2 was the least efficient of the retrofit hybrid units. The lower efficiency of this model was due to the lower thermal efficiency ( $80 \%$ for this model compared to $90+\%$ for others) and the large storage volume (40 gal). At lower usage rates the standby heat loss had a large impact on the daily efficiency and WH 2 performed comparably to other water heaters with similar storage volumes (condensing storage water heaters and natural draft storage water heaters). At higher usage rates where the thermal efficiency became more important the daily efficiencies responded accordingly. At 55 gpd the natural draft storage water heater had an average efficiency of $50 \%$, where the hybrid WH 2 was $70 \%$, and the condensing storage water heater was $84 \%$, with average thermal efficiencies of approximately $70 \%, 80 \%$, and $94 \%$. 


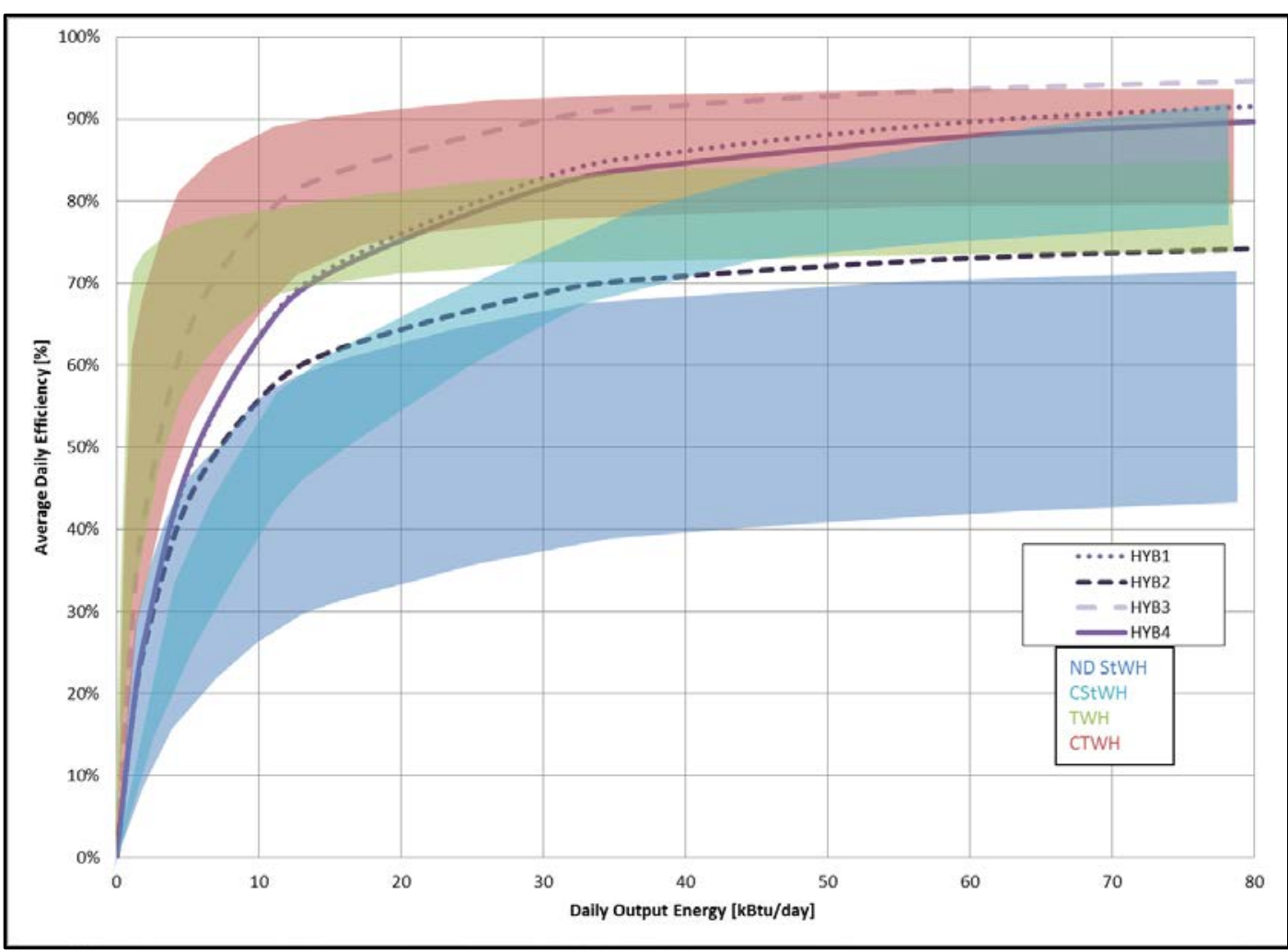

Figure 21. Comparison of the efficiency of retrofit hybrid water heaters to other high-efficiency gas water heaters 


\section{Conclusions}

The water heaters tested for this project were designed to improve the cost-effectiveness and increase market penetration of high-efficiency water heaters in the residential retrofit market. The four water heaters tested in this project achieved that goal by:

- Reducing the installation cost of high-efficiency water heaters

- Maintaining significant reductions in water heating energy consumption

- Providing some storage capacity to ensure that occupants are satisfied with the water delivery quality.

By eliminating the need for upgrading gas lines and meters and reducing the venting clearance requirements and installation difficulties, these water heaters minimized the installation costs for high-efficiency water heaters. Further reductions in installation costs for these products could only be achieved by targeting the new construction market where changes and upgrades are less expensive to implement, reducing the cost of the water heaters themselves, or increasing the baseline technology market wide. The natural draft venting of baseline water heaters requires hot exhaust air to properly vent out to the exterior of the home. The higher the efficiency of the water heater, the lower the exhaust air temperature. Although the hybrid water heater design did minimize the change from low efficiency to high, the cost of adding new venting for high efficiency will be avoided only when the existing housing market shifts to the new vent type. This would occur if the water heater market shifts from natural draft to power or direct vent models.

The design changes required to minimize installation costs did not come at the expense of energy savings. Figure 21 shows that these hybrid water heaters delivered installed efficiencies within the same range of other high-efficiency natural gas water heating systems, such as condensing storage water heaters and condensing tankless water heaters. Hybrid WH 2 was the least efficient of the water heaters tested and the least efficient of all high-efficiency water heaters. At lower usage rates (below 40,000 Btu/d), it was more comparable to a standard-efficiency appliance.

Each of the hybrid water heaters included in this study combined some storage capacity with a higher capacity burner. The storage capacity and improved controls for these water heaters improved the ability to provide hot water consistently and quickly for most hot water events. However, data analysis showed that homeowner satisfaction was unlikely to be impacted by installing one of these water heaters.

The retrofit high-efficiency water heaters achieved their goal of reducing costs, maintaining savings, and meeting the necessary capacity to improve cost-effectiveness. However, the improvements were not sufficient to achieve simple paybacks of less than 10 years when compared to minimum-efficiency heaters. In most cases the paybacks were as long as or longer than the expected lifetime of the water heater. Significant changes would be necessary to reduce the simple payback to 6 years or less. Incremental costs less than $\$ 400$ would have paybacks of 6 years, but they would require a large reduction in the water heater equipment cost or a change in the typical water heater installation. Annual energy savings in the range of \$200 would also reduce paybacks to less than 6 years. These energy savings would require either higher fuel costs 
(greater than $\$ 1.50$ per therm) or very high usage (around $120 \mathrm{gpd}$ ). For current fuel and incremental equipment costs, an increase in water heater efficiency to that of a heat pump water heater would also deliver 6-year paybacks. 


\section{References}

Bohac, David, Ben Schoenbauer, Martha Hewett, Mary Sue Lobenstein, and Thomas Butcher. 2010. "Actual Savings and Performance of Natural Gas Tankless Water Heaters." Research Final Report. Minneapolis, MN: Center for Energy and Environment. http://mncee.org/getattachment/f1b02561-9854-4b82-85e2-5e6c9ef728ee/.

D\&R International. 2006. "2006 Buildings Energy Data Book.” U.S. Department of Energy. http://buildingsdatabook.eren.doe.gov/docs\%5CDataBooks\%5C2006_BEDB.pdf.

Energy Efficiency and Renewable Energy Office (EERE). 2011. "Docket: Test Procedures for Residential Water Heaters and Certain Commercial Water Heaters (EERE-2011-BT-TP-0042)." Docket Folder. http://www.regulations.gov/\#!docketDetail;D=EERE-2011-BT-TP-0042.

Hoeschele, Marc. 2012. "Field Monitoring of Advanced Gas Water Heaters in Eighteen California Homes." Presented at the Exploring the Disconnect Between Rated and Field Performance of Water Heating Systems, Golden, CO, September 28.

National Renewable Energy Laboratory. 2013. "Building America Technical Innovations Leading to 50\% Savings - A Critical Path.” Unpublished Building America report.

National Renewable Energy Laboratory. 2014. "National Residential Efficiency Measures Database.” National Renewable Energy Laboratory. http://www.nrel.gov/ap/retrofits/.

Schoenbauer, Ben. 2012. "Installed Performance of Water Heaters and Combination Systems." Presented at the BA Experts Meeting on Exploring the Disconnect Between Rated and Field Performance of Water Heating Systems, Golden, CO, September 29. 


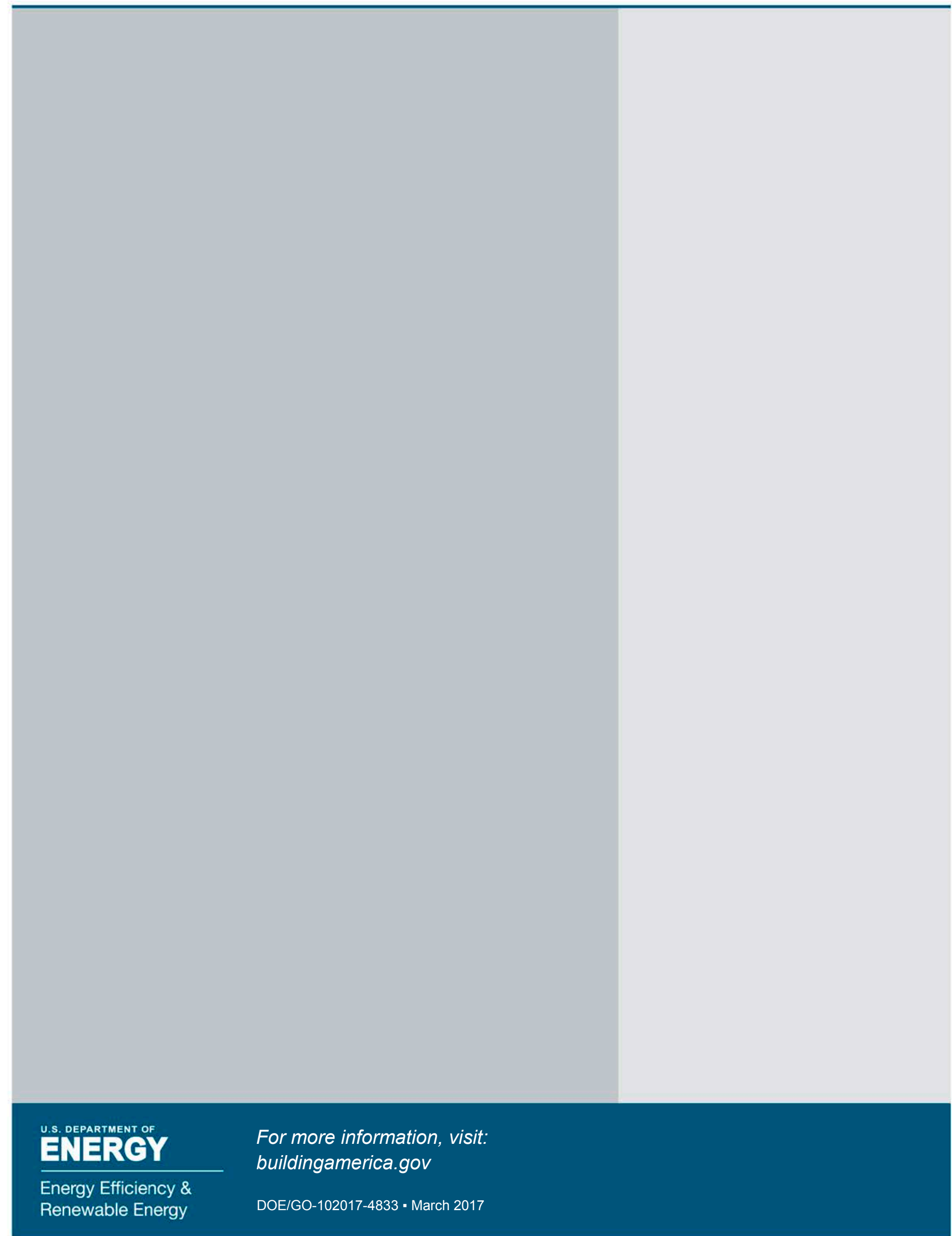

